\title{
Article \\ Core Predictors of Debt Specialization: A New Insight to Optimal Capital Structure
}

\author{
Kanwal Iqbal Khan ${ }^{1}$, Faisal Qadeer ${ }^{2}$, Mário Nuno Mata ${ }^{3,4, * \mathbb{C}}$, José Chavaglia Neto ${ }^{5}$, Qurat ul An Sabir ${ }^{6,7}$, \\ Jéssica Nunes Martins ${ }^{8,9}$ and José António Filipe ${ }^{10}$
}

1 Institute of Business \& Management, University of Engineering and Technology, Lahore 54000, Pakistan; kanwal.khan@uet.edu.pk

2 Lahore Business School, The University of Lahore, Lahore 54000, Pakistan; drfaisalqadeer@gmail.com

3 ISCAL-Instituto Superior de Contabilidade e Administração de Lisboa, Instituto Politécnico de Lisboa, Avenida Miguel Bombarda 20, 1069-035 Lisboa, Portugal

4 Polytechnic Institute of Santarém, School of Management and Technology (ESGTS-IPS), 2001-904 Santarém, Portugal

5 Fundação Getúlio Vargas (EESP-FGV), Itapeva Street, São Paulo 01332-000, Brazil; jnchavaglia@gmail.com

6 School of Statistics, Minhaj University Lahore, Lahore 54000, Pakistan; qurratulan.stat@mul.edu.pk

7 Biofluids and Biosystems Modelling Lab (BBML), Department of Engineering, Faculty of Agriculture, Dalhousie University, Halifax, NS B3H 4R2, Canada

8 NOVA Information Management School, (NOVA IMS), Universidade Nova de Lisboa, Campus de Campolide, 1070-312 Lisboa, Portugal; jessicanunesmartins@gmail.com or jessica.cristina.martins@bancobpi.pt

9 BPI-Banco Portugês de Investimento-CaixaBank Group, Accounting Department, Largo Jean Monnet $19^{\circ}$ andar, 1269-067 Lisboa, Portugal

10 Departamento de Matemática, Iscte-Instituto Universitário de Lisboa, ISTAR-Iscte, BRU-Iscte, 1649-026 Lisboa, Portugal; Jose.filipe@iscte.pt

check for updates

Citation: Khan, K.I.; Qadeer, F.; Mata, M.N.; Chavaglia Neto, J.; Sabir, Q.u.A.; Martins, J.N.; Filipe, J.A. Core Predictors of Debt Specialization: A New Insight to Optimal Capital Structure. Mathematics 2021, 9, 975. https://doi.org/10.3390/math9090975

Academic Editor: Christoph Frei

Received: 28 January 2021

Accepted: 22 April 2021

Published: 27 April 2021

Publisher's Note: MDPI stays neutral with regard to jurisdictional claims in published maps and institutional affiliations.
* Correspondence: mnmata@iscal.ipl.pt or mario.mata@esg.ipsantarem.pt

\begin{abstract}
Debt structure composition is an essential topic of discussion for the management of capital structure decisions. Researchers made extensive efforts to understand the criteria for selecting debts, specifically, to know about the reasons for debt specialization, concealed in identifying its predictors. This question is essential not only for establishing the field of debt structure but also for the financial managers to design corporate financial strategy in a way that leads to attaining an optimal debt structure. Sophisticated financial modeling is applied to identify the core predictors of debt specialization, influencing the strategic choices of optimal debt structure to address this issue. Data were collected from 419 non-financial companies listed at the Karachi Stock Exchange from 2009 to 2015. This study has validated debt specialization by showing that short-term debts maintain their position over the years and remain the most popular type of loan among Pakistani firms. Further, it provides a comprehensive view of the cross-sectional differences among the firms involved in debt specialization by applying a holistic approach. Results show that small, growing, dividend-paying companies, having high expense and risk ratios, followed the debt specialization strategy. This strategy enables firms to reduce their agency conflicts, transaction costs, information asymmetry, risk management and building up their good market reputation. Conclusively, we have identified the gross profit margin, long-term debt to asset ratio, firm size, age, asset tangibility, and long-term industry debt to asset ratio as reliable and core predictors of debt specialization for sustainable business growth.
\end{abstract}

Keywords: debt specialization; corporate financial strategy; optimal debt structure; agency conflicts; transaction cost; information asymmetry; financial modeling; risk management

\section{Introduction}

In today's competitive environment, financing decisions are of utmost importance for achieving sustainable business growth [1]. That is why management put an effort to 
select the best combination of debt and equity that reduces agency conflicts and plays an essential role in building a good image of the company in the market. However, financial decisions have become arduous due to the complex menu of choices. It has become difficult for managers to decide the best combination for debt structure in the modern business environment. Prior literature focuses on the broad capital structure alternatives; debt and equity $[2,3]$. In comparison, recent empirical studies are evident in the increasing tendency of debt financing among organizations over the century [4].

This increasing dependence is because of the restructuring and development of the financial market that introduces new avenues for lending and makes debt structure composition a widely researched topic in finance [5]. Now scholars have become more curious to know why some firms include a single loan type (debt specialization) in their debt structure, while others rely on multiple sources of financing (debt diversification) [6]. Debt diversification is a commonly employed strategy used to mitigate default risk. However, the concept of debt specialization is still emerging and requires to be theoretically advanced by identifying more of its conceptually related predictors.

Previously, very few studies are conducted, mainly in the United States [7-9] and in a few emerging economies [7-9], to confirm its existence. However, the cross-country studies of capital structure divulge that previously identified capital structure determinants, established in the United States, are unable to explain capital structure decisions outside the United States, both in developed [10] and developing countries [11]. Even though capital structure theories are unable to justify the financing behavior of the companies located in different countries because of their cultural, economic, and institutional disparities, which increases the chances of the existence of similar conditions across nations. Therefore, it is essential to testify the identified factors and discover some new predictors of debt specialization, especially in developing countries.

Another reason for studying this topic is that most debt structure studies focused on traditional organizational factors [12]. Colla [13] identified twelve organizational and one non-organizational factor as determinants of debt specialization. Rauh [14] also reported the correlation between the traditional determinants of capital structure and different types of debt to vary a lot. However, Lemmon [15] claimed that the features of leverage are largely unexplained by the previously identified determinants. Graham [4] confirmed this notion by identifying the organizations' inability to explain variations in the debt structure over time due to some omitted organizational factors that need to be defined in the literature or because of macroeconomic factors. That is why prior studies are unable to report the core predictors of debt specialization. Specifically, all the studies talked about the measurement issues and suggested the inclusion of more organizational and non-organizational factors.

The current study uses an ambitious approach by taking a variety of factors with a larger dataset to identify the reliable and robust factors to the firm's debt specialization choice. It first analyzes the trends of the debt market and confirms the existence of debt specialization. Then it explains the characteristics of the firms that solely rely on fewer types of debt. It also discusses the applicability of debt specialization across organizations and finally identifies the core predictors. In this way, it tries to reconcile the contradictory findings in the prior literature [16].

The use of an emerging market and the extensive data population employed is also a remarkable contribution to the current study in the context of an emerging economy. This depicts an accurate picture of the existence and prevalence of the debt specialization strategy among Pakistani companies. The present study includes thirty-nine organizational and non-organizational companies divided into thirteen categories. It also uses the panel data of 419 publicly traded companies from 2009 to 2015. This study is one of the prime studies investigating the most reliable factors of debt specialization from a long list of factors from the prior literature that testifies the identified factors and finds out some new antecedents of debt specialization. 
This study enhances our understanding of capital structure literature and contributes to the field in several ways: First, it enriches the debt structure literature by substantially extending the empirical research on the predictors of debt specialization. This will further contribute to the large and growing literature on the causes of debt specialization by its theoretical explanation. Previously, traditional organizational factors are used as antecedents of debt specialization, but it includes a wide variety of factors and finds out the most reliable and core predictors among them. It amplifies the scope of the study and helps to generalize the predictors of debt specialization across organizations.

Second, there is a long-continued debate on the differences regarding capital structure in developed and developing countries [9-11]. Researchers like Malik [8] also emphasized exploring the concept in the context of developing counties. So, this is one of our contributions, that we discussed the types of loan and pattern of borrowings in developing counties. Third, it will add to the growing literature of debt specialization by scrutinizing the vast spectrum of antecedents. Starting with a comprehensive list of thirty-nine factors, we classified them into thirteen categories by capital structure theories, empirical studies, and connected logic. In this way, it not only extends the work of Colla [13] but also provides the new area of research to the scholars. Finally, one of the unique features of the current study is that it includes some distinct factors like business group affiliation, total asset turnover, return on asset volatility, and a set of growth ratios, as the predictors of debt specialization that are rarely used in the capital structure study. It extends the earlier studies by incorporating more explanatory factors to its estimation and ran a horse-race to identify the most relevant predictors of debt specialization.

This paper is organized as follows: Section 2 provides an overview of the theories of capital structure and prior literature related to predictors of debt specialization; Section 3 discusses research design and methodology; Section 4 discusses the major findings of the study and its discussion; and Section 5 describes conclusion, limitation of the current research, and future directions.

\section{Theories and Literature Review}

\subsection{Theories of Capital Structure}

The most significant capital structure theory is the trade-off theory based on Modigliani and Miller's propositions. It emphasizes balancing the cost of financial distress and tax shield benefits under the static and dynamic setting. Its ultimate target is to achieve an optimal capital structure [17]. Static trade-off theory concentrates on a single period leverage decision that follows the notion of optimal debt ratio to minimize the costs (agency and financial distress) [18] against the benefits of tax shield [19]. On the other hand, a dynamic trade-off theory discusses the dynamic elements of time that are usually ignored by the single-period capital structure model [20].

As opposed to the trade-off theory, the pecking order theory does not believe in the optimal leverage ratio obtained by weighing the cost and benefit of debt [21]. It instead suggests that the capital structure decisions are related to selecting appropriate financing sources over time to minimize the adverse selection costs. This theory argues that organizations first utilize their internal funds; if it is not sufficient, then go for debt financing. If still, these sources are unable to meet their funding requirements, then, in the end, they rely on equity financing technique as a last resort [22]. Debt prefers on equity due to collateral provision [23] and monitoring benefit [24], reducing financing cost and information asymmetry. However, Elsas [25] changed the pattern of borrowing by replacing retained earnings with equity instead of debt which keeps the leverage level unchanged.

Market timing theory advocates that financial managers consider market timing before issuing equity or debt. This theory does not believe in the notion of optimal capital structure. It gives weightage to the current market situation and states that the companies should issue shares only in case of favorable stock market conditions when the shares are overvalued and purchases them back when undervalued [25]. Therefore, managers do not 
have an optimal capital structure in their minds when they decide their debt and equity ratios. They merely take advantage of the stock market conditions [26].

Signaling theory is another critical theory associated with capital structure decisions. It documents that organizations often use capital structure information to propagate their reputation in the market [27] and only issue debt or equity in the presence of positive feedback. This theory is based on asymmetric information that explains how firms use their financial information to publicize their ability to meet future growth challenges.

Agency cost theory predicts that an optimal capital structure can be achieved by minimizing the conflict of interest between various stakeholders, i.e., management, shareholders, and debt holders [28]. Managers who own the company's shares often exploit the rights of the other claim holders. Shareholders of a leveraged firm have an incentive to invest in riskier projects with a high return rate because, in the case of adverse selection, they will face only a limited downturn in their share value. In contrast, debt holders tend to prefer less risky investments with guaranteed returns. Therefore, Alderson [29] and Barclay [30] claimed that the agency costs spawned by risk-shifting activities could be controlled using either short-term or secured debts.

The agency problem is also one reason why the pecking order theory predicts that outside capital is more expensive. All these theories play a considerable role in understating the financial policy decisions of the organizations. However, various aspects of these theories are supported and sometimes disproved empirically by scholars over time [31]. Therefore, we can posit that neither of the views successfully explains much of the heterogeneity in capital structures [3]. A single theory cannot sufficiently clarify the time series and cross-sectional variations in the capital structure choices.

\subsection{Literature Review and Theoretical Predictions for Predictors of Debt Specialization}

\subsubsection{Liquidity}

Liquidity factors indicate the firms' ability to meet their short-term obligations [32,33] and are positively associated with the degree of debt specialization. Companies with more cash balances have more tendency towards debt specialization, especially during the period of crisis [34]; both smaller and larger companies maintain high cash balances. Small companies often have restricted access to the debt market, so they keep more cash balances to meet their working capital requirements [35]. This notion is supported by the pecking order theory, where companies are maintaining a larger amount of cash, utilize their internal funds first, and then go for debt financing. Liquidity factors help manage short-run fluctuations of the external financing deficit [36,37]. Locorotondo [38] also claimed that companies could avoid market imperfections such as the cost of financial distress, agency cost, asymmetric information, and transaction cost by maintaining high cash ratios.

Measure: (a) Cash Holding (CR); (b) Current Ratio (CR).

\subsubsection{Profitability}

Profitability factors are considered the most consistent and essential predictors in capital structure studies in emerging economies [11]. That is why they are regarded as necessary for debt specialization decisions. Previous studies showed that profitable firms mostly use diversified debt structures that negatively affect debt specialization. Trade-off theory, agency cost, taxes, and bankruptcy cost all push the profitable organizations towards the high level of debts as these companies earn high profits to shelter their marginal taxes and having fewer chances of insolvency $[38,39]$. This shows that the profitable companies capital structure comprises more debt instruments to gain the added advantages of tax shields, apart from the other benefits of higher debt. The expected cost of bankruptcy declines when profitability increases.

The detectability of interest payments for tax purposes forces profitable firms to prefer debt financing. A high fraction of pre-interest earnings is an indication of a positive relationship between debt and profitability. Profitability helps to solve agency conflict by forcing managers to pay more out of the excess cash available to the organizations [28]. 
This notion also works as a positive signaling mechanism for investors and lenders [40]. In contrast, the pecking order theory carries different implications about this relationship. Debt ratios are expected to have a negative association with profitability [41]. It predicts profitable organizations use less debt, regardless of how the debt ratio is defined.

Conversely, Kaya [42] explained no association between profitability and debt structure choices. These conflicting results show that there is no clear pattern for this relationship. It stimulates the current study to find out the relationship between profitability and debt specialization.

Measure: (a) Gross Margin Ratio (GMR); (b) EBITDA Margin Ratio (EBITDA); (c) Net Profit Ratio (NPR).

\subsubsection{Leverage}

Leverage is the degree to which an organization is financed with borrowed money [32,43]. These factors are traditionally used to explain debt structure variations. Previously, researchers considered that the firms with the same leverage ratios use a similar type of debt, but later on, it was proved that organizations employ different compositions of debt with identical debt ratios [14,44]. Some organizations borrow few debt types, while others use diversified debt types with the same debt ratio. This approach motivates the current study to include leverage factors as the determinants of debt specialization and expects that debt specialization is positively related to the lower leverage ratios. This association is also recently supported by [21].

Measure: (a) Financial Leverage (FL); (b) Market Leverage (ML); (c) Long-term Debt to Asset (LDA).

\subsubsection{Nature of Assets}

The nature of assets is explained based on asset tangibility and asset turnover ratio. Asset tangibility was integrated into the model to signify the impact of collateralized assets on the organizations' leverage-related decisions. It indicates the asset quality to meet the debt burden. The collateralized debts increase the company's value, and thus the optimal strategy for the companies is to issue more secured debts. A high level of asset tangibility and higher asset turnover ratio indicates a high level of security to the claim holders. It makes the debt less risky as if a company gets bankrupt; then enough assets are available to fulfill the claims of the creditors [18]. Several empirical studies have documented the importance of these factors on leverage decisions of the organizations $[10,11,45]$. However, only the role of asset tangibility is explored from the debt specialization perspective, which is still obscure. As on the one side, Rauh [14] explained that companies having more tangible assets use more types of debt. Still, few scholars like Alderson [29] reported no difference in selecting debts due to asset tangibility.

A theoretical explanation for this relationship is also available in the literature. Agency cost theory predicts the behavior of financial institutions that they carefully observed the investment patterns of the leveraged companies. Overinvestment creates agency conflicts between the debt holders and shareholders. However, if a company has more tangible assets and a high asset turnover ratio, these conflicts can be easily solved [28]. This also minimizes the likelihood of financial distress and bankruptcy, which supports the trade-off theory [18]. These factors also reduce information asymmetry and make equity issuance less costly [19]. All this evidence is also supported by the trade-off, pecking order, and agency cost theories. Thus, it is suggested that both the factors are inversely related to the debt specialization decision of the firms.

Measure: (a) Asset Tangibility (AT); (b) Total Asset Turnover Ratio (TATR).

\subsubsection{Risk}

Risk factors are the critical measure of financial distress or debt default costs; that is why they are considered to be the essential antecedent of debt specialization. These factors are expected to be positively related to debt specialization. Organizations with volatile 
earnings may experience agency-related issues and often face high financial distress costs. To minimize their chances of bankruptcy, they have to adjust their debt structure and use the debt specialization strategy to reduce the probability of default $[39,46]$. Empirical results unanimously represent that earnings volatility is inversely related to debt types [3].

Another aspect of this relationship is that sometimes investors and lenders cannot predict their future earnings based on publicly available information. Therefore, lenders demand a higher premium for their debts. These results are consistent with the trade-off and pecking order theories that predict a negative relationship between volatility and selection of debts because high volatility increases the chances of bankruptcy [18]. So, in this situation, companies use the debt specialization strategy. We used different risk factors, including earnings volatility, return on asset volatility and Altman's Z-score (default risk) for measurement.

Measure: (a) Earnings Volatility (EV); (b) Default Risk (DR); (c) Return on Asset Volatility (ROAV).

\subsubsection{Growth}

Growth is the indicator of expected investment opportunities with high explanatory power to illustrate debt structure variations [47]. Growth opportunities are intangible and often cause information asymmetry between insiders and outsiders. It is the capital asset for the company that added value in the future but does not generate income [48,49]. Agency cost is higher for the high growth firms because managers of the leveraged companies are engaged in asset substitution and over and underinvestment activities that create agencyrelated problems between shareholders' debt holders $[28,45]$. The growing companies have more chances at bankruptcy as their value precipitously falls when the cost of financial distress increases [19,41]. Agency cost theory predicts that organizations with more growth opportunities face higher information asymmetries and, therefore, face more borrowing constraints [38]. This prohibits them from including more types of debts in their debt structure. Additionally, Fama [26] claimed that the pecking order theory is consistent with small growth firms' behavior, which is more inclined to use internal funding than external financing. Therefore, it is posited that companies with high growth opportunities incline more towards debt specialization.

Measure: (a) Asset Growth (AG); (b) Revenue Growth (RG); Earnings Growth (EG).

\subsubsection{Controlling Authority}

Controlling authority is the authoritative power and ascendancy over autonomous business enterprises. It is responsible for directing and managing the operations of the related business entities. Business groups are one of the types of controlling authority. They are autonomous legal entities that share common ownership and administrative control [50]. Substantial research has been conducted to understand the role of business groups. Empirical evidence demonstrates that they play a notable role in sharing risk among their member organizations [51] and act as an alternative to the external capital market [38]. Financial institutions consider them more trustworthy for issuing debts due to their cross debt guarantees $[52,53]$.

Business group helps remove market inefficiencies in developing countries and improve their performance. The performance of affiliated companies is better than nonaffiliated companies in the presence of an imperfect market, high government interference, weak supporting institutions, and legal system [54]. They have greater access to limited resources, so by utilizing these resources efficiently, they can lower their cost and increase their profits [55]. Pecking order theory is a true representative of business groups. As the pecking order theory predicts that companies first utilize their internal funds for financing and then seek external resources in the form of either debt or equity [41].

Similarly, business groups first utilize their internal capital, and if these funds are not sufficient, they go for debt financing. A group-affiliated organization with a credit rating is considered the most eligible candidate for external funding [56]. These are 
the causes that make business groups attractive for many researchers to look into this peculiar structure and find out how they contribute to the debt financing decisions of their affiliates. Although pecking order theory supports business groups, very few studies [57] are available that explain the importance of business groups in selecting debt types. None of the studies still explore their role regarding debt specialization decisions. Based on all these empirical and theoretical justifications, this study expects the negative relation between debt specialization and business group affiliation.

Measure: (a) Business Group Affiliation (BGA).

\subsubsection{Market}

Age, size, and market-to-book ratio can be market factors for organizations. Debt specialization depends on the firms' size, but the role of size is still vague in the literature. On the one side, trade-off theory describes the positive role of size due to its greater access to the debt market [30] and fewer chances of bankruptcy. Smaller companies have more likelihood of liquidation than the larger companies, and thus they are likely to have less leverage. Additionally, large companies tend to be more diversified [45], have superior debt capacity, and are more likely to get loans on favorable terms. Such companies face lower agency costs associated with asset substitution and underinvestment problems [49] and are therefore expected to maintain high leverage ratios.

While on the other side, pecking order theory predicts the role of size as a proxy for information asymmetry between insiders or outsiders and suggests a negative relationship between size and leverage [58] than smaller companies. On average, big companies raise more significant amounts of capital than the smaller companies due to economies of scale, e.g., the lower percentage fixed flotation cost. Therefore, they can issue more informationsensitive instruments like public debts than smaller companies that tend to borrow from banks [24,42]. Sometimes they even prefer to issue equity on debt, and in that case, size is negatively associated with debt [18]. Larger organizations can achieve economies of scale while smaller face financial constraints that force them to choose a concentrated debt structure [38].

Age is the time in years since the company announces its first IPO. It is considered a significant image-building factor that reduces agency problems, information asymmetries, and financial distress costs [21]. Older companies are more reputable, credible, and mature than younger companies. This increases their accessibility to the external debt markets, and they are in a better position to borrow from diversified types of debts. Previous studies also represent opposite results regarding age. Some scholars believe that companies that use more types of debt are mature [59]. Therefore, they expect a negative relation with debt specialization, while others consider that age is unable to explain variation in the debt structure [12]. A high market-to-book ratio leads a firm to include fewer types of debt. It conveys a positive signal about the company's quality, reducing agency conflicts and information asymmetries between shareholders and debt holders [60,61]. Therefore, it is posited that companies with high growth opportunities incline more towards debt specialization.

Measure: (a) Size (Size); (b) Age (Age); (c) Quality (Qual.) Market to Book Ratio (MBR).

\subsubsection{Expenses}

Expenses explain the financial efficiency and asset management of the organization. High expense ratios reduce earnings, increase the likelihood of bankruptcy, agency cost and information, and monitoring cost. They also provide wrong signals about the performance of the organization to the stakeholders. All these theoretical justifications support trade-off, pecking order, agency cost, and signaling theories. Based on these theoretical predictions, both expense ratios will be positively related to the organization's debt specialization decision [21].

Prior studies showed that generally, high corporate tax rates favor debt, while high personal tax rates favor equity. An optimal debt structure is determined by the trade-off 
between the benefits of taxes and the cost of financial distress [17]. Organizations with high tax rates issue more debts as the deductibility of interest payment from the profit implies greater interest tax shields benefits and therefore induces higher leverage [61].

Measure: (a) Depreciation Ratio (Dep.); (b) Operating Expense Ratio (OER); (c) Tax Ratio (TR).

\subsubsection{Debt Market}

Debt market factors include credit rating, financial ratio, and interest coverage ratio. Credit rating is the primary determinant of the debt market, explaining the nature of the debt patterns and sources for the organizations [62]. Debt structure varies by the change in credit quality. Organizations with high credit ratings have easy access to the debt market and, therefore, utilize diversified debt types $[63,64]$. The notion is supported by trade-off, agency cost, and asymmetric information theories [18]. Rating reduces the probability of default, agency conflicts, and information asymmetries among stakeholders. However, the results of Rauh [14] claimed that low-rated companies use multiple tiers of debt while high-rated companies mostly rely either on senior unsecured debt or equity. This provides support to the pecking order theory.

The financial ratio and interest coverage ratio also affect the debt specialization decision of the organizations. They determine the organization's ability to pay a debt obligation [65]. Trade-off theory illustrates that a company will trade-off their tax benefits with debt cost when deciding their capital structure. If their debt cost is higher, they try to avoid debts or sometimes approach the equity [18]. Usually, the cost of debt is higher for those organizations that employ few debt types, while organizations with diversified debt structures face the least cost [34]. Therefore, lower financial ratios and interest coverage ratios are expected to be positively related to debt specialization.

Measure: (a) Credit Rating (Rating); (b) Financial Ratio (FR); (c) Interest Coverage Ratio (ICR).

\subsubsection{Stock Market}

Stock market conditions affect the financing decisions of the firms. Financial managers consider market timing before issuing debt or equity [66]. They issue financial instruments only in case of favorable conditions. Stock market factors are inversely related to the leverage only when this decision is taken under unfavorable market conditions [64]. When firms increase the debt ratio in their capital structure, it may adversely impact their stock prices because debt-related interest payments reduce the dividend payments $[33,67]$. That is why both stock market factors, dividend payout ratio and dividend yield, are negatively related to the debt specialization decision of the organizations [15].

Measure: (a) Dividend Payers (DP); (b) Dividend Payout Ratio (DPR); (c) Dividend Yield (DY).

\subsubsection{Industry}

Corporate finance theories report the crucial role of market imperfections (i.e., taxes, information asymmetry) on capital structure decisions [11,58]. Scholars like Rajan [10] also believe that industry-level factors are detrimental to capital structure decisions [10]. Joeveer [61] supports this notion that variation in leverage is mainly explained by industry factors, especially in the long run. Therefore, this study considers industry factors; regulation, median industry leverage ratios, and median industry growth ratios are important to significantly explain the effects of debt specialization decisions for organizations [68].

Regulations are the rules and regulations imposed by the regulatory authorities related to an industry. Trade-off theory supports the regulation factor. The organizations maintain stable cash flows and thus have fewer chances of bankruptcy [69]. The regulation also reduces the information asymmetries and agency conflicts between shareholders and debt holders [70] and can obtain loans from multiple sources. That is why it is posited that regulated organizations incline less towards debt specialization. Financial managers often 
use median industry growth and leverage ratios to benchmark for their organizations [18]. Median industry leverage is the median value of leverage, and median industry growth is the median value of the growth for all the organizations that existed in the specific industry during the particular year under study $[15,71]$. Trade-off theory suggests that organizations with higher median industry leverage use less debt, while organizations with higher median industry growth ratios use more debt [2]. Therefore, it is posited that the median industry leverage has a negative relation, while the median industry growth ratio has a positive association with debt specialization.

Measure: (a) Regulation (Reg.); (b) Median Industry Financial Leverage (MIFL); (c) Median Industry Market Leverage (MIML); (d) Median Industry Long-term Debt to Asset (MILDA); (e) Median Industry Asset Growth (MIAG); (f) Median Industry Revenue Growth (MIRG); (g) Median Industry Earnings Growth (MIEG).

\subsubsection{Macroeconomic}

The fluctuations in the economic environment can play a prominent role in explaining corporate financial policy variations. Sometimes, it adversely affects the organizational accessibility to the debt market [48], particularly in an economic downturn [61]. During the depression period, stock prices went down, and the expected cost of financial distress increased the chances of bankruptcy. Agency relationships become more severe in this situation; information and monitoring also are cost increases that induce organizations to use debt specialization strategy [67]. The trade-off, pecking order, and market timing theories also support this relationship. Macroeconomic factors include government borrowing, expected inflation rate, and GDP growth. Graham [4] found a negative relationship between government borrowing and leverage yet a positive association between GDP growth and leverage [37] and also between leverage and the expected inflation rate [61].

Measure: (a) Government Borrowing (GB); (b) Expected Inflation Rates (EIR); (c) GDP Growth (GDPG).

To sum up, all these theoretical, empirical, and logical justifications provide the basis for the current study and explain the significance of including all the organizational and non-organizational factors as the antecedents of debt specialization. Based on these foundations, we can answer the proposed research questions. However, the possible explanation for the reasons of debt specialization is still necessary to be known.

\section{Materials and Methods}

\subsection{Data Collection and Sample Description}

The current study uses unbalanced panel data extracted from multiple sources: Firstly, the primary source of data collection for debt specialization, and its predictors, were the analysis reports of Karachi Stock Exchange and State Bank of Pakistan. We use the same definitions in constructing these variables as in Colla [13] and Khan [6]. Secondly, the annual time series data related to macroeconomic conditions were taken from the World Development Indicator from 2009 to 2015. Thirdly, credit rating information was extracted from the published reports of credit rating agencies (Pakistan Credit Rating Agency and Japan Credit Rating-Vital Information Services). Fourthly, data for business group affiliation were plucked from the annual reports and websites of the firms. Finally, information about stock market prices was taken from the online database of business recorders, a leading newspaper.

This study examines all publicly traded non-financial firms that remained listed at Karachi Stock Exchange from 2009 to 2015. We also apply different sample selection rules: first, we identify the companies with available financial information, which results in 419 non-financial firms with 2933 company-year observations. We then eliminate (1) firms with zero or missing firm-year observation for total assets and debts, i.e., 51 firm-year observations; (2) Book, market, and financial leverage outside the unit interval (34 firm-year observations); (3) Organizations with zero cash holding (25 firm-year observations); (4) Further, all continuous organizational and non-organizational firm characteristic variables 
are winsorized at 1st and 99th percentiles that cause the removal of further 28 firm-year observations; and finally, end up at "2795 firm-year" observations.

\subsection{Measurement}

Debt specialization is the tendency to rely predominantly on fewer debt types or even on a single type of debt. It is measured through the numeric way, where we quantify the numerical variable, the degree of debt specialization across various firms. It is evaluated by Herfindahl-Hirschman Index (HHI) for all debt types included in the firms' debt structure $[12,13,16,72]$. It is calculated as follows:

$$
S S_{i, t}=\left(\frac{S_{S D}, t}{T D_{i, t}}\right)^{2}+\left(\frac{O_{S D}, t}{T D_{i, t}}\right)^{2}+\left(\frac{L S D_{i, t}}{T D_{i, t}}\right)^{2}+\left(\frac{L U N D_{i, t}}{T D_{i, t}}\right)^{2}+\left(\frac{D E B_{i, t}}{T D_{i, t}}\right)^{2}+\left(\frac{O_{L D} D_{i, t}}{T D_{i, t}}\right)^{2}
$$

where $S_{\mathrm{i}, t}$ is the sum of squared debt type ratios for the organization ' $i$ ' in year ' $t$ '; while SSD, OSD, LSD, LUND, DEB, and OLD stand for the debt types. Next, we obtain:

$$
\mathrm{HHI}_{\mathrm{i}, \mathrm{t}}=\frac{\mathrm{SS}_{\mathrm{i}, \mathrm{t}-\frac{1}{6}}}{1-\frac{1}{6}}
$$

The value of debt specialization lies between " 0 " and " 1 ", where " 1 " indicates that a firm employs a single type of debt in its debt structure, while " 0 " explains that it includes all debt types in a specific proportion [73]. The higher value of $\mathrm{HHI}$ is the indication of the greater degree of debt specialization among the organizations. Further, Table 1 provides a detailed description of the factors used in the analysis based on their empirical and theoretical justifications, along with the expected relation directions. The detail of Acronym is provoded in Table A1 in Appendix A.

\begin{tabular}{|c|c|c|c|c|c|c|}
\hline \multirow{2}{*}{\multicolumn{2}{|c|}{ Explanatory Variables }} & \multirow{2}{*}{$\begin{array}{l}\text { Expected } \\
\text { Relations }\end{array}$} & \multirow{2}{*}{ Measurements } & \multicolumn{2}{|c|}{ Relation Found in Prior Studies } & \multirow{2}{*}{$\begin{array}{c}\text { Theories \& } \\
\text { Predicted Signs }\end{array}$} \\
\hline & & & & Positive & Negative & \\
\hline \multirow[t]{2}{*}{ Liquidity } & $\mathrm{CH}$ & Positive & $\frac{(\text { Cash }+ \text { Short Term Investments })}{\text { Total Assets }}$ & $\begin{array}{l}\text { Colla [13]; } \\
\text { Florackis [33]; } \\
\text { Tengulov [34] }\end{array}$ & & \multirow{2}{*}{$\begin{array}{l}\mathrm{TO}(+) \\
\mathrm{PO}(+) \\
\mathrm{AC}(-)\end{array}$} \\
\hline & CR & Positive & $\frac{\text { Current Assets }}{\text { Current Liability }}$ & $\begin{array}{c}\text { Basu [36]; } \\
\text { Pessarossi [37] }\end{array}$ & & \\
\hline \multirow{3}{*}{ Profitability } & GMR & Negative & $\frac{\text { Gross Profit }}{\text { Revenue }}$ & Abor [74] & & \multirow{3}{*}{$\begin{array}{l}\mathrm{TO}(-) \\
\mathrm{PO}(+) \\
\mathrm{AC}(-) \\
\mathrm{S}(-)\end{array}$} \\
\hline & EBITDA & Negative & $\frac{\text { EBITDA }}{\text { Revenue }}$ & Delen [75] & & \\
\hline & NPR & Negative & $\frac{\text { EBIT }}{\text { Revenue }}$ & $\begin{array}{c}\text { Danis [39]; } \\
\text { Elsas [25]; Li [76] }\end{array}$ & $\begin{array}{l}\text { Basu [36]; } \\
\text { Colla [13]; } \\
\text { Graham [4] }\end{array}$ & \\
\hline \multirow{3}{*}{ Leverage } & FL & Negative & $\frac{\text { Total Debt }}{\text { Book Value of Assets }}$ & Povoa [12] & $\begin{array}{c}\text { Colla [13]; } \\
\text { Florackis [33]; } \\
\text { Li [76]; Lou [77]; } \\
\text { Tengulov [34] }\end{array}$ & \multirow{3}{*}{$\begin{array}{l}\mathrm{TO}(-) \\
\mathrm{AC}(-)\end{array}$} \\
\hline & ML & Negative & $\frac{\text { Total Debt }}{(\text { Total Debts }+ \text { MV of Equity })}$ & & $\begin{array}{l}\text { Alderson [29]; } \\
\text { Tengulov [34] }\end{array}$ & \\
\hline & LDA & Negative & $\frac{\text { Long Term Debt }}{\text { Book Value of Assets }}$ & & $\begin{array}{l}\text { Albring [70]; } \\
\text { Colla [13] }\end{array}$ & \\
\hline \multirow{2}{*}{$\begin{array}{l}\text { Nature of } \\
\text { Asset }\end{array}$} & $\mathrm{AT}$ & Negative & $\frac{\text { (Tangible Assets }+ \text { Inventory) }}{\text { Total Assets }}$ & Povoa [12] & $\begin{array}{l}\text { Colla [13]; Li [76]; } \\
\text { Lou [77] }\end{array}$ & \multirow{2}{*}{$\begin{array}{l}\mathrm{TO}(-) \\
\mathrm{PO}(-) \\
\mathrm{AC}(-)\end{array}$} \\
\hline & TATR & Negative & $\frac{\text { Revenue }}{\text { Total Assets }}$ & & Shah [78] & \\
\hline
\end{tabular}

Table 1. Summary for predictors of debt specialization. 
Table 1. Cont.

\begin{tabular}{|c|c|c|c|c|c|c|}
\hline \multirow{2}{*}{\multicolumn{2}{|c|}{ Explanatory Variables }} & \multirow{2}{*}{$\begin{array}{l}\text { Expected } \\
\text { Relations }\end{array}$} & \multirow{2}{*}{ Measurements } & \multicolumn{2}{|c|}{ Relation Found in Prior Studies } & \multirow{2}{*}{$\begin{array}{c}\text { Theories \& } \\
\text { Predicted Signs }\end{array}$} \\
\hline & & & & Positive & Negative & \\
\hline \multirow{3}{*}{ Risk } & EV & Positive & $\frac{\text { (SD of PBT\&Dep.) }}{\text { Average Assets }}$ & $\begin{array}{l}\text { Danis [39]; } \\
\text { Povoa [12] }\end{array}$ & & \multirow{3}{*}{$\begin{array}{l}\mathrm{TO}(+) \\
\mathrm{PO}(+) \\
\mathrm{AC} \mathrm{(+)} \\
\mathrm{S}(-)\end{array}$} \\
\hline & DR & Positive & 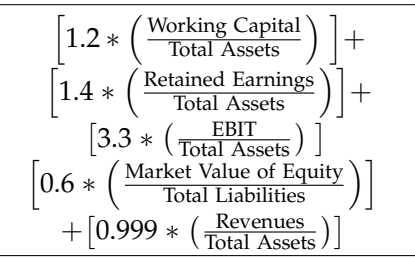 & $\begin{array}{l}\text { Alderson [29]; } \\
\text { Wang [79] }\end{array}$ & & \\
\hline & ROAV & Positive & $\begin{array}{l}\text { It is the standard deviation of } \\
\text { operating income divided by } \\
\text { total assets over the previous } 7 \\
\text { years }\end{array}$ & Meneghetti [65] & & \\
\hline \multirow{3}{*}{ Growth } & AG & Negative & $\frac{\left(\text { BV of Assets } t_{t}-\text { BV of Assets } t_{t-1}\right)}{\text { BV of Assets } t_{t}}$ & Basu [36] & Chang [59] & \multirow{3}{*}{$\begin{array}{l}\mathrm{TO}(+) \\
\mathrm{PO}(-) \\
\mathrm{AC}(+) \\
\mathrm{S}(-)\end{array}$} \\
\hline & RG & Positive & $\frac{\left(\text { Revenues }_{t}-\text { Revenues }_{t-1}\right)}{\text { Revenues }_{t-1}}$ & Erel [48] & & \\
\hline & EG & Negative & $\frac{\left(\text { Earnings }_{t}-\text { Earnings }_{t-1}\right)}{\text { Earnings }}$ & & Shah [78] & \\
\hline $\begin{array}{l}\text { Controlling } \\
\text { Authority }\end{array}$ & BGA & Negative & $\begin{array}{l}\text { " } 1 \text { " if a company is a group } \\
\text { affiliated, " } 0 \text { " if it is unaffiliated. }\end{array}$ & & $\begin{array}{c}\text { Bamiatzi [50]; } \\
\text { He [54]; } \\
\text { Locorotondo [38]; } \\
\text { Wang [79] }\end{array}$ & $\begin{array}{l}\mathrm{TO}(-) \\
\mathrm{PO}(-) \\
\mathrm{AC}(-) \\
\mathrm{S}(-)\end{array}$ \\
\hline \multirow[t]{3}{*}{ Market } & Size & Negative & The logarithm of Total Assets & & $\begin{array}{c}\text { Colla [13]; } \\
\text { Danis [39]; } \\
\text { Elsas [25]; } \\
\text { Florackis [33]; } \\
\text { Li [76]; Lou [77]; } \\
\text { Povoa [12] }\end{array}$ & \multirow{3}{*}{$\begin{array}{l}\mathrm{TO}(-) \\
\mathrm{PO}(+) \\
\mathrm{AC}(-) \\
\mathrm{S}(+)\end{array}$} \\
\hline & Age & Positive & $\begin{array}{l}\text { Time in years since the company } \\
\text { announces its first IPO }\end{array}$ & & $\begin{array}{l}\text { Chang [59]; } \\
\text { Colla [13]; } \\
\text { Povoa [12]; } \\
\quad \text { Li [76] }\end{array}$ & \\
\hline & MBR & Negative & $\frac{\text { Market Value of Equity }}{\text { Book Value of Equity }}$ & $\begin{array}{l}\text { Colla [13]; } \\
\text { Danis [39]; } \\
\text { Lou [77]; } \\
\text { Tengulov [34] }\end{array}$ & $\begin{array}{l}\text { Povoa [12]; } \\
\quad \mathrm{Li}[76]\end{array}$ & \\
\hline \multirow{3}{*}{$\begin{array}{l}\text { Nature of } \\
\text { Expenses }\end{array}$} & Dep. & Positive & $\frac{\text { Depreciation Expenses }}{\text { Total Fixed Assets }}$ & $\begin{array}{l}\text { Chang [59]; } \\
\text { Elsas [25] }\end{array}$ & & \multirow{3}{*}{$\begin{array}{l}\mathrm{TO}(+) \\
\mathrm{PO}(+) \\
\mathrm{AC}(+)\end{array}$} \\
\hline & OER & Positive & $\frac{\text { Operating Expenses }}{\text { Revenues }}$ & $\begin{array}{l}\text { Colla [13]; } \\
\text { Frank [2] }\end{array}$ & & \\
\hline & TR & Negative & $\frac{\text { Tax Expenses During the Year }}{\text { Profit Before Tax }}$ & & Shah [78] & \\
\hline \multirow{3}{*}{ Debt Market } & Rating & Negative & $\begin{array}{l}\text { " } 1 \text { " if the firm is rated, } \\
\text { " } 0 \text { " otherwise }\end{array}$ & & $\begin{array}{c}\text { Colla [13]; } \\
\text { Danis [39]; } \\
\text { Elsas [25]; Li [76]; } \\
\text { Povoa [12] }\end{array}$ & $\begin{array}{l}\mathrm{TO}(-) \\
\mathrm{PO}(+) \\
\mathrm{AC}(-) \\
\mathrm{S}(+)\end{array}$ \\
\hline & FR & Negative & $\frac{\text { Financial Expenses }}{\text { Net Revenues }}$ & $\begin{array}{l}\text { Meneghetti [65]; } \\
\text { Tengulov [34] }\end{array}$ & & \multirow{2}{*}{$\begin{array}{l}\mathrm{TO}(+) \\
\mathrm{PO}(+) \\
\mathrm{AC}(+)\end{array}$} \\
\hline & ICR & Negative & $\frac{\text { EBIT }}{\text { Interest Expenses }}$ & Khan [21] & & \\
\hline \multirow{3}{*}{ Stock Market } & DP & Positive & $\begin{array}{c}\text { " } 1 \text { " if a company pays either } \\
\text { cash or stock dividends, } \\
\text { " } 0 \text { " otherwise. }\end{array}$ & Lemmon [15] & Li [76]; Lou [77] & \multirow{3}{*}{$\begin{array}{c}\mathrm{PO}(+) \\
\mathrm{MT}(+) \\
\mathrm{S}(+)\end{array}$} \\
\hline & DPR & Positive & $\frac{\text { Total Amount of Cash Dividend }}{\text { Total Net Income }}$ & $\begin{array}{l}\text { Aggarwal [80]; } \\
\text { Florackis [33] }\end{array}$ & & \\
\hline & DY & Positive & $\frac{\text { Annual Dividend }}{\text { Current Stock Price }}$ & Tengulov [34] & & \\
\hline
\end{tabular}


Table 1. Cont.

\begin{tabular}{|c|c|c|c|c|c|c|}
\hline \multirow{2}{*}{\multicolumn{2}{|c|}{ Explanatory Variables }} & \multirow{2}{*}{$\begin{array}{l}\text { Expected } \\
\text { Relations }\end{array}$} & \multirow{2}{*}{ Measurements } & \multicolumn{2}{|c|}{ Relation Found in Prior Studies } & \multirow{2}{*}{$\begin{array}{l}\text { Theories \& } \\
\text { Predicted Signs }\end{array}$} \\
\hline & & & & Positive & Negative & \\
\hline \multirow{3}{*}{ Industry } & Reg. & Positive & $\begin{array}{l}\text { " } 1 \text { " if the company is in a } \\
\text { regulated industry and } \\
\text { " } 0 \text { " otherwise }\end{array}$ & $\begin{array}{l}\text { Albring [70]; } \\
\text { Basu [36]; } \\
\text { Elsas [25]; } \\
\text { Frank [2]; } \\
\text { Graham [4] }\end{array}$ & & $\begin{array}{l}\mathrm{TO}(+) \\
\mathrm{PO}(+) \\
\mathrm{AC} \mathrm{(+)} \\
\mathrm{S}(+)\end{array}$ \\
\hline & MIL & Negative & $\begin{array}{l}\text { Median of leverage values } \\
\text { (financial, long-term debt to } \\
\text { asset and market) for all } \\
\text { organizations of the industry } \\
\text { during the year }\end{array}$ & & $\begin{array}{l}\text { Denis [71]; } \\
\text { Chang [59]; } \\
\text { Joeveer [61] }\end{array}$ & $\begin{array}{l}\mathrm{TO}(-) \\
\mathrm{AC}(-)\end{array}$ \\
\hline & MIG & Negative & $\begin{array}{l}\text { Median values of growth } \\
\text { (Revenue and market to book) } \\
\text { for all organizations of the } \\
\text { industry during the year. }\end{array}$ & & $\begin{array}{c}\text { Chang [81]; } \\
\text { Frank [2] }\end{array}$ & $\begin{array}{l}\mathrm{TO}(+) \\
\mathrm{PO}(-) \\
\mathrm{AC}(+) \\
\mathrm{S}(-)\end{array}$ \\
\hline \multirow{3}{*}{ Macroeconomic } & GB & Positive & $\frac{\text { Federal Debt }}{\text { GDP }}$ & Graham [4] & & \multirow{3}{*}{$\begin{array}{l}\mathrm{PO}(+) \\
\mathrm{MT}(+) \\
\mathrm{S}(+)\end{array}$} \\
\hline & EIR & Positive & $\frac{\left(\mathrm{CPI}_{\mathrm{t}}-\mathrm{CPI}_{\mathrm{t}-1}\right)}{\mathrm{CPI}_{\mathrm{t}}}$ & Graham [4] & $\begin{array}{l}\text { Chang [59]; } \\
\text { Joeveer [61] }\end{array}$ & \\
\hline & GDPG & Negative & $\frac{\left(\mathrm{GDP}_{\mathrm{t}}-\mathrm{GDP}_{\mathrm{t}-1}\right)}{\mathrm{GDP}_{\mathrm{t}-1}}$ & & $\begin{array}{l}\text { Chang [59]; } \\
\text { Graham [4]; } \\
\text { Joeveer [61] }\end{array}$ & \\
\hline
\end{tabular}

$A C=$ Agency Cost, $M T=$ Market Timing, $P O=$ Pecking Order, $S=$ Signaling, $T O=$ Trade-off.

\subsection{Estimation Methods for Unbalanced Panel Data and Model Specifications}

The current study has employed the panel data approach for 419 non-financial listed companies from 2009 to 2015. It employs a Tobit regression model that the corporate finance scholars use to estimate the fractional dependent variables $[29,82,83]$. These models provide better statistical inference on the estimated parameters and significantly advance the standard theories. Therefore, this study uses a Tobit regression model because the dependent variable, "debt specialization" calculated based on HHI, which is fractional in nature and values are bounded between zero and on, is both inclusive. Tobit regression models vigorously depend on the assumptions of linearity, normality, and homoscedasticity. The absolute value of skewness and kurtosis (i.e., between $|2|$ ) indicates a normal distribution of the data [84]. If the normality assumption is met, then the relationship between variables is also homoscedastic [85], as homoscedasticity is associated with the assumption of normality [86]. Table 1 presents the results of skewness and kurtosis for all study variables. Equation (1) presented the study model, which includes the main categories of predictors: liquidity, profitability, leverage, nature of assets, risk, growth, controlling authority, market, nature of expenses, debt market, stock market, industry, macroeconomics. The detail of each category is mentioned in Table 1.

$$
\begin{aligned}
\mathrm{HHI}_{\mathrm{t}}= & \alpha_{\mathrm{t}}+\beta_{1} \mathrm{LIQ}_{\mathrm{t}}+\beta_{2} \mathrm{PROF}_{\mathrm{t}}+\beta_{3} \mathrm{LEV}_{\mathrm{t}}+\beta_{4} \mathrm{NOA}_{\mathrm{t}}+\beta_{5} \mathrm{RISK}_{\mathrm{t}}+\beta_{6} \mathrm{GROW}_{\mathrm{t}}+\beta_{7} \mathrm{CA}_{\mathrm{t}}+ \\
& \beta_{8} \mathrm{MARK}_{\mathrm{t}}+\beta_{9} \mathrm{NOE}_{\mathrm{t}}+\beta_{10} \mathrm{DM}_{\mathrm{t}}+\beta_{11} \mathrm{SM}_{\mathrm{t}}+\beta_{12} \mathrm{IND}_{\mathrm{t}}+\beta_{13} \mathrm{MACRO}_{\mathrm{t}}+\varepsilon_{\mathrm{t}}
\end{aligned}
$$

\section{Results}

\subsection{Debt Structure Overview}

Figure 1 provides an overview of the trends of financing patterns in Pakistan for the period of 2009 to 2015. We have divided the debt pattern into two major categories: Short-term and long-term; then, we further segregated them into six types. Figure 1 shows that short-term loans (short-term secured and other short-term loans) are quite popular in the debt market, comprise on average $65 \%$ of the total debt (See Table 2). This has provided strong evidence for the existence of debt specialization. Short-term secured debt has an increasing trend over the years. In the long-term debt category, long-term secured debts are the most common type of loan among Pakistani firms, while debentures seem to be 
the least important. In Table 2, a significant year-to-year change in debt composition is observed between the sample firms in developing countries like Pakistan. In contrast, Rauh [14] found no significant year-to-year change in debt level but reported a substantial variation in the debt structure composition of the sample firms.

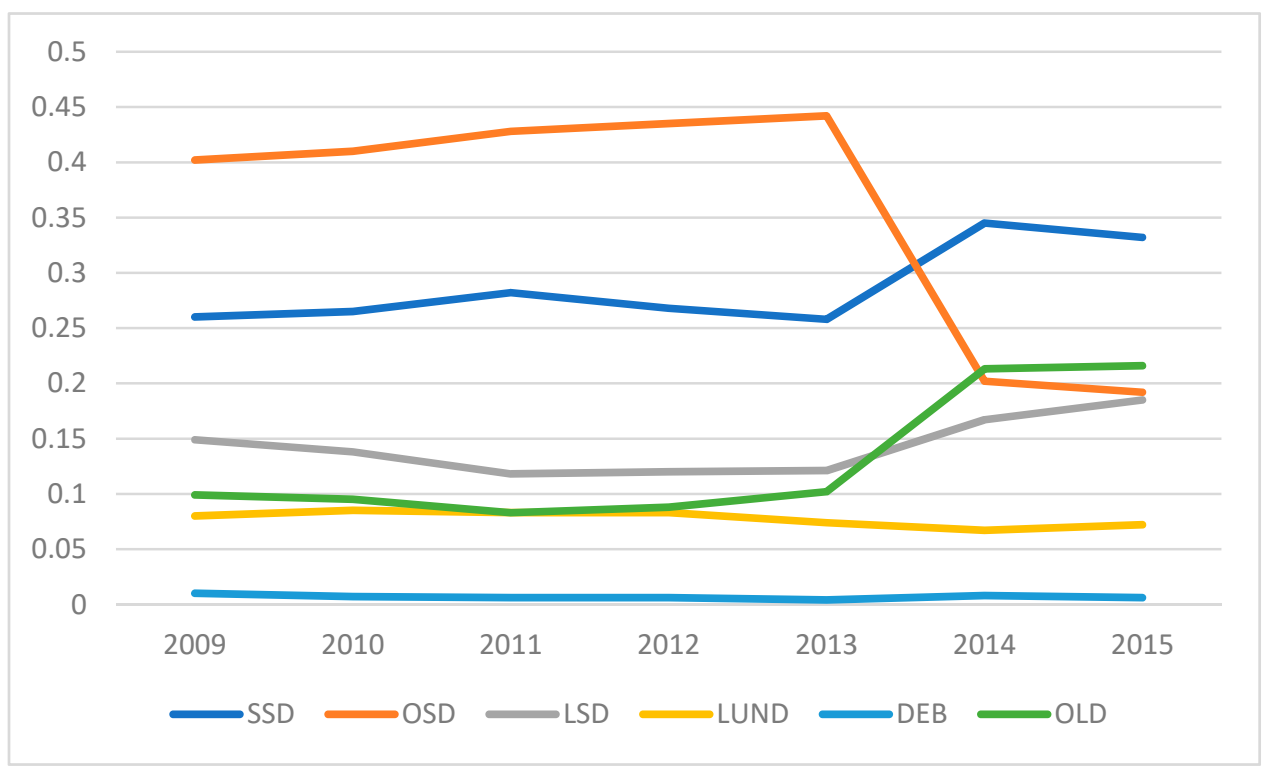

Figure 1. Debt types and debt specialization over time.

Table 2. Descriptive statistics for debt types.

\begin{tabular}{|c|c|c|c|c|c|c|c|c|c|c|}
\hline \multirow{2}{*}{$\begin{array}{l}\text { Types of } \\
\text { Debts }\end{array}$} & \multirow{2}{*}{ Mean } & \multicolumn{7}{|c|}{ Percentile } & \multirow{2}{*}{ SD } & \multirow{2}{*}{$\begin{array}{l}\text { Obs. with Positive } \\
\text { Usage (\%) }\end{array}$} \\
\hline & & 10th & 25th & 50 th & 75th & 90th & 95th & 99th & & \\
\hline SSD & 0.287 & 0.000 & 0.008 & 0.242 & 0.490 & 0.673 & 0.770 & 0.770 & 0.266 & 76.82 \\
\hline OSD & 0.360 & 0.027 & 0.121 & 0.272 & 0.546 & 0.888 & 1.000 & 1.000 & 0.300 & 98.14 \\
\hline LSD & 0.142 & 0.000 & 0.000 & 0.039 & 0.221 & 0.452 & 0.581 & 0.858 & 0.202 & 58.03 \\
\hline LUND & 0.078 & 0.000 & 0.000 & 0.000 & 0.045 & 0.301 & 0.501 & 0.918 & 0.184 & 31.95 \\
\hline DEB & 0.007 & 0.000 & 0.000 & 0.000 & 0.000 & 0.000 & 0.000 & 0.295 & 0.048 & 4.11 \\
\hline OLD & 0.127 & 0.000 & 0.001 & 0.054 & 0.162 & 0.350 & 0.538 & 1.000 & 0.191 & 75.85 \\
\hline
\end{tabular}

\subsection{Descriptive Statistics}

Table 3 shows the descriptive statistics for the study variables. The results show that Pakistani firms have a more significant tendency towards debt specialization. The policy of these companies is to maintain high liquidity ratios so that they can meet their debt obligations within a business cycle. Custodio [83] and Locorotondo [38] also supported this by arguing that firms with high liquidity ratios can efficiently manage their shortrun fluctuations of external financing deficit and avoid market imperfections. Although these companies hold $70 \%$ tangible assets at present, their total asset turnover ratio is approximately 1.64, which highlighted the efficiency of Pakistani firms in utilizing their total assets for the generation of revenue.

The leverage ratios of sample firms exhibit significant differences in their value, whereas previously, scholars like Frank [2] reported minor variations in the leverage ratios. These variations may be due to the rapid changes in the market value of equity and assets that cause differentiation in the denominator of the ratios. The growth factors present that the market to book ratio $(81 \%)$ is better than revenue growth $(6 \%)$ for a similar reason. The expenses ratios are higher than the profitability ratios, indicating that loss-bearing firms are also part of our sample. 
Table 3. Summary statistics for Pakistani listed firms.

\begin{tabular}{|c|c|c|c|c|c|c|c|c|c|}
\hline \multirow{2}{*}{ Variables } & \multirow{2}{*}{ Mean } & \multirow{2}{*}{ SD } & \multicolumn{5}{|c|}{ Percentiles } & \multirow{2}{*}{ Skewness } & \multirow{2}{*}{ Kurtosis } \\
\hline & & & 10th & 25th & 50th & 75th & 90th & & \\
\hline \multicolumn{10}{|c|}{ Debt Specialization } \\
\hline $\mathrm{HHI}$ & 0.438 & 0.266 & 0.158 & 0.233 & 0.368 & 0.564 & 0.931 & 0.858 & 1.654 \\
\hline \multicolumn{10}{|c|}{ i. Liquidity } \\
\hline $\mathrm{CH}$ & 0.057 & 0.111 & 0.001 & 0.004 & 0.013 & 0.053 & 0.163 & 0.170 & -0.878 \\
\hline CR & 1.096 & 0.485 & 0.550 & 0.850 & 1.030 & 1.270 & 1.700 & 1.063 & 1.498 \\
\hline \multicolumn{10}{|c|}{ ii. Profitability } \\
\hline GMR & 0.013 & 0.924 & -0.348 & 0.013 & 0.047 & 0.112 & 0.349 & 1.628 & 1.921 \\
\hline EBITDA & -0.038 & 1.210 & -0.271 & -0.023 & 0.027 & 0.890 & 0.218 & 0.957 & 1.297 \\
\hline NPR & -0.057 & 1.243 & -0.418 & -0.082 & 0.004 & 0.070 & 0.196 & 1.880 & 1.729 \\
\hline \multicolumn{10}{|c|}{ iii. Leverage } \\
\hline FL & 0.515 & 0.238 & 0.175 & 0.337 & 0.534 & 0.696 & 0.814 & -0.215 & -0.735 \\
\hline ML & 0.635 & 0.283 & 0.187 & 0.417 & 0.698 & 0.882 & 0.959 & -0.576 & -0.848 \\
\hline LDA & 0.197 & 0.202 & 0.006 & 0.039 & 0.135 & 0.287 & 0.471 & 1.459 & 2.007 \\
\hline \multicolumn{10}{|c|}{ iv. Nature of Assets } \\
\hline $\mathrm{AT}$ & 0.695 & 0.215 & 0.373 & 0.590 & 0.749 & 0.853 & 0.920 & -1.078 & 0.767 \\
\hline TATR & 1.641 & 1.243 & 0.236 & 0.790 & 1.192 & 1.584 & 1.784 & 2.008 & 1.854 \\
\hline \multicolumn{10}{|c|}{ v. Risk } \\
\hline EV & 0.288 & 0.135 & 0.160 & 0.200 & 0.260 & 0.340 & 0.450 & 1.613 & 3.658 \\
\hline DR & 1.274 & 1.333 & -0.337 & 0.432 & 1.232 & 2.137 & 2.978 & -0.064 & 0.159 \\
\hline ROAV & 0.027 & 0.138 & -0.092 & -0.025 & 0.023 & 0.079 & 0.156 & -0.538 & 1.475 \\
\hline \multicolumn{10}{|c|}{ vi. Growth } \\
\hline$A G$ & 0.037 & 0.235 & -0.148 & -0.045 & 0.030 & 0.134 & 0.258 & -1.211 & 1.460 \\
\hline RG & 0.064 & 0.359 & -0.364 & -0.105 & 0.063 & 0.237 & 0.473 & 0.071 & 1.613 \\
\hline EG & 0.306 & 1.939 & -1.372 & -0.233 & 0.238 & 0.854 & 1.984 & 0.151 & 1.333 \\
\hline \multicolumn{10}{|c|}{ vii. Controlling Authority } \\
\hline BGA & 0.572 & 0.495 & 0.000 & 0.000 & 1.000 & 1.000 & 1.000 & -0.292 & -1.916 \\
\hline \multicolumn{10}{|c|}{ viii. Market } \\
\hline Size & 3.361 & 0.867 & 2.328 & 2.867 & 3.403 & 3.942 & 4.408 & -0.564 & 1.759 \\
\hline Age & 21.853 & 7.516 & 9.000 & 19.000 & 23.000 & 27.000 & 30.000 & -0.975 & 0.450 \\
\hline MBR & 0.811 & 0.551 & 0.020 & 0.420 & 0.770 & 1.140 & 1.560 & 0.558 & -0.032 \\
\hline \multicolumn{10}{|c|}{ ix. Expense } \\
\hline Dep. & 0.080 & 0.124 & 0.016 & 0.036 & 0.059 & 0.090 & 0.120 & 1.129 & 1.635 \\
\hline OER & 0.146 & 0.234 & 0.022 & 0.038 & 0.065 & 0.159 & 0.325 & 0.903 & 0.903 \\
\hline TR & 0.159 & 0.324 & -0.090 & 0.000 & 0.140 & 0.319 & 0.467 & 0.126 & 1.897 \\
\hline \multicolumn{10}{|c|}{ x. Debt Market } \\
\hline Rating & 0.163 & 0.462 & 0.000 & 0.000 & 0.000 & 0.000 & 1.000 & 0.402 & 0.787 \\
\hline FR & 0.072 & 0.161 & 0.004 & 0.008 & 0.030 & 0.062 & 0.139 & 1.211 & 2.031 \\
\hline ICR & 0.033 & 0.019 & 0.019 & 0.020 & 0.029 & 0.033 & 0.076 & 1.697 & 1.404 \\
\hline \multicolumn{10}{|c|}{ xi. Stock Market } \\
\hline DP & 0.455 & 0.498 & 0.000 & 0.000 & 0.000 & 1.000 & 1.000 & 0.182 & -1.968 \\
\hline DPR & 0.119 & 0.251 & 0.000 & 0.000 & 0.000 & 0.144 & 0.460 & 1.888 & 1.549 \\
\hline DY & 0.038 & 0.107 & 0.000 & 0.000 & 0.000 & 0.033 & 0.093 & 1.155 & 1.424 \\
\hline
\end{tabular}


Table 3. Cont.

\begin{tabular}{|c|c|c|c|c|c|c|c|c|c|}
\hline \multirow{2}{*}{ Variables } & \multirow{2}{*}{ Mean } & \multirow{2}{*}{ SD } & \multicolumn{5}{|c|}{ Percentiles } & \multirow{2}{*}{ Skewness } & \multirow{2}{*}{ Kurtosis } \\
\hline & & & 10th & 25th & 50th & 75th & 90th & & \\
\hline \multicolumn{10}{|c|}{ xii. Industry } \\
\hline Reg. & 0.206 & 0.404 & 0.000 & 0.000 & 0.000 & 0.000 & 1.000 & 1.457 & 0.122 \\
\hline MIFL & 0.666 & 0.181 & 0.420 & 0.554 & 0.692 & 0.812 & 0.888 & -0.742 & 0.246 \\
\hline MIML & 0.583 & 0.100 & 0.453 & 0.519 & 0.592 & 0.666 & 0.708 & -0.443 & -0.121 \\
\hline MILDA & 0.140 & 0.077 & 0.044 & 0.074 & 0.147 & 0.184 & 0.240 & 0.390 & 0.468 \\
\hline MIAG & 0.058 & 0.459 & -0.034 & -0.076 & 0.026 & 0.217 & 0.249 & -1.245 & 1.978 \\
\hline MIRG & 0.079 & 0.146 & -0.106 & 0.000 & 0.068 & 0.138 & 0.264 & 0.077 & 1.565 \\
\hline MIEG & 0.326 & 1.521 & -1.245 & -0.658 & 0.163 & 0.532 & 1.875 & 1.114 & 1.840 \\
\hline \multicolumn{10}{|c|}{ xiii. Macroeconomic } \\
\hline GB & 0.008 & 0.004 & 0.006 & 0.007 & 0.007 & 0.008 & 0.010 & 1.120 & 2.931 \\
\hline EIR & 0.086 & 0.032 & 0.025 & 0.067 & 0.088 & 0.120 & 0.122 & -0.569 & -0.529 \\
\hline GDPG & 0.147 & 0.058 & 0.092 & 0.097 & 0.124 & 0.229 & 0.241 & 0.787 & -1.148 \\
\hline
\end{tabular}

The risk factors, including earnings volatility: $29 \%$, return on asset volatility: $2.7 \%$, and default risk: 1.274 , are relatively high, which can be an alarming situation for emerging countries like Pakistan. Default risk is measured by Altman Z-Score model where, Z-Score lesser than 1.81 represents a company with a "higher chance of default," between 1.81 and 3.0 means the "caution" or "danger" zone and, finally, Z-Score greater than 3.0 represents a company with a safe financial situation. Z-Score results signify that listed companies of the Karachi Stock Exchange have a higher likelihood of bankruptcy. These findings are supported by previous studies where the scholars believe that debt specialization is more prevalent among companies with high default probability [13].

About $57 \%$ of the sample firms are affiliated group, suggesting the ownership structure of Pakistani companies is mostly concentrated. Family firms mostly rule in all the business sectors. The average age of the firms is about 22 years, indicating most of them are mature and medium-sized. Further, $84 \%$ do not have a credit rating, and $79 \%$ are nonregulatory, which shows that the Pakistani credit rating and regulatory agencies are not actively working, which is a common phenomenon among the emerging economies. The benchmark industry growth ratios (MIRG: 7.9\%) are higher than the average growth rates. This difference may be due to the inclusion of all categories of firms within the industry, i.e., old or new, small or large, profitable or loss bearing, regulatory or non-regulatory, etc. The dividends paying ratio is about $46 \%$, with a nearly $12 \%$ payout ratio. However, $\mathrm{SECP}$ is now making strict rules and binding the listed companies to announce dividends regularly.

All the standard deviation values are less than one, which means there is little dispersion from the average. All and all, the results are reliable and can be generalized to the whole sample. The absolute values of skewness and kurtosis (i.e., between $|2|$ ) indicate a normal distribution of the data [84]. All the study variables completely fulfill the normality assumption in the case of skewness except earnings volatility (3.658), financial ratio (2.031), and government borrowings (2.931) that remain unsupportive in the case of kurtosis only. However, some researchers believe that the benchmark value for skewness is $|2|$, whereas kurtosis is $|7|$ for normality [87]. Based on this condition, all study variables fulfill the criteria of normality.

\subsection{Which Organizations Specialize?}

Table 4 presents a detailed explanation of the cross-sectional differences in specialization among the listed firms of Pakistan. For this purpose, we adopted Colla [13] and combined all the organizational and non-organizational factors to explain which firms are involved in debt specialization substantially. 
Table 4. Which organizations specialize?

\begin{tabular}{|c|c|c|c|c|c|c|c|}
\hline \multirow{2}{*}{ Variables } & \multirow{2}{*}{ Correlation } & \multicolumn{2}{|c|}{ 1st Quartile } & \multicolumn{2}{|c|}{ 4th Quartile } & \multicolumn{2}{|c|}{ Test of Differences } \\
\hline & & Mean & Median & Mean & Median & $t$-Test & Wilcoxon Test \\
\hline $\mathrm{CH}$ & $0.285^{* * *}$ & 0.035 & 0.009 & 0.106 & 0.036 & $-10.434^{* * *}$ & $-9.671^{* * *}$ \\
\hline CR & $0.0282 * * *$ & 1.054 & 0.958 & 2.011 & 1.447 & $-12.448^{* * *}$ & $-11.180^{* * *}$ \\
\hline GMR & $0.050 * *$ & 0.022 & 0.163 & 0.042 & 0.233 & $-2.271^{* *}$ & $-4.111^{* * *}$ \\
\hline EBITDA & $0.002 *$ & -0.059 & 1.098 & -0.053 & 1.554 & -0.105 & $-5.186^{* * *}$ \\
\hline NPR & $0.037^{*}$ & -0.067 & -0.008 & 0.041 & 0.024 & -1.544 & $-5.664^{* * *}$ \\
\hline FL & $-0.301^{* * *}$ & 0.587 & 0.607 & 0.405 & 0.375 & $15.002^{* * *}$ & $-14.061^{* * *}$ \\
\hline ML & $-0.329^{* * *}$ & 0.737 & 0.817 & 0.499 & 0.52 & $16.303^{* * *}$ & $-14.309 * * *$ \\
\hline LDA & $-0.314^{* * *}$ & 0.299 & 0.259 & 0.111 & 0.02 & $18.559 * * *$ & $-23.071^{* * *}$ \\
\hline AT & $-0.331^{* * *}$ & 0.778 & 0.814 & 0.594 & 0.621 & $15.938^{* * *}$ & $-13.693^{* * *}$ \\
\hline TATR & $0.251^{* * *}$ & 2.505 & 3.808 & 6.537 & 11.727 & $-9.465^{* * *}$ & $-6.745^{* * *}$ \\
\hline EV & $0.179^{* * *}$ & 0.081 & 0.065 & 0.128 & 0.079 & $-7.593^{* * *}$ & $-5.689^{* * * *}$ \\
\hline DR & $0.084^{* * *}$ & 1.16 & 1.052 & 1.463 & 1.506 & $-4.208^{* * *}$ & $-4.723^{* * *}$ \\
\hline ROAV & $0.074^{* * *}$ & 0.022 & 0.022 & 0.045 & 0.03 & $-2.957^{* * *}$ & $-3.040 * * *$ \\
\hline $\mathrm{AG}$ & $-0.045^{* *}$ & 0.046 & 0.032 & 0.024 & 0.014 & $1.667 *$ & -1.734 * \\
\hline RG & $-0.129^{* * *}$ & 0.127 & 0.12 & 0.004 & 0.023 & $6.412^{* * *}$ & $-6.741^{* * *}$ \\
\hline EG & $-0.038^{* *}$ & 0.387 & 0.382 & 0.197 & 0.156 & 1.884 * & $-3.112^{* * *}$ \\
\hline BGA & $-0.104^{* * *}$ & 0.624 & 1.000 & 0.499 & 0.000 & $4.778^{* * *}$ & $-4.741^{* * *}$ \\
\hline Size & $-0.221^{* * *}$ & 3.479 & 3.405 & 3.073 & 3.141 & $8.231^{* * *}$ & $-6.889^{* * *}$ \\
\hline Age & $0.073^{* * *}$ & 25.843 & 23.000 & 29.689 & 26.000 & $-4.890 * * *$ & $-4.467^{* * *}$ \\
\hline MBR & $0.069^{* * *}$ & 0.770 & 0.478 & 1.007 & 0.740 & $-3.506^{* * *}$ & $-3.689 * * *$ \\
\hline Dep. & $0.080^{* * *}$ & 0.063 & 0.052 & 0.091 & 0.063 & $-4.542 * * *$ & $-3.722 * * *$ \\
\hline OER & $0.157^{* * *}$ & 0.102 & 0.051 & 0.191 & 0.092 & $-7.266^{* * *}$ & $-7.583^{* * *}$ \\
\hline $\mathrm{TR}$ & $0.038^{* *}$ & 0.142 & 0.113 & 0.184 & 0.173 & $-2.482 * *$ & $-3.003^{* * *}$ \\
\hline Rating & -0.014 & 0.189 & 0.000 & 0.150 & 0.000 & 1.37 & $-3.939^{* * *}$ \\
\hline FR & $-0.088^{* * *}$ & 0.083 & 0.044 & 0.051 & 0.006 & $4.112^{* * *}$ & $-18.405^{* * *}$ \\
\hline ICR & $-0.104^{* * *}$ & 0.035 & 0.030 & 0.030 & 0.022 & $5.502 * * *$ & $-9.263^{* * *}$ \\
\hline $\mathrm{DP}$ & $0.068^{* * *}$ & 0.384 & 0.000 & 0.503 & 1.000 & $-4.497^{* * *}$ & $-4.466^{* * *}$ \\
\hline DPR & $0.154^{* * *}$ & 0.068 & 0.000 & 0.174 & 0.000 & $-8.048^{* * *}$ & $-6.407^{* * *}$ \\
\hline DY & 0.021 & 0.036 & 0.000 & 0.042 & 0.001 & -1.113 & $-4.481^{* * *}$ \\
\hline Reg. & $0.171^{* * *}$ & 0.123 & 0.000 & 0.289 & 0.000 & $-7.862^{* * *}$ & $-7.513^{* * *}$ \\
\hline MIFL & $-0.208^{* * *}$ & 0.61 & 0.635 & 0.553 & 0.539 & $11.026^{* * *}$ & $-10.771^{* * *}$ \\
\hline MIML & $-0.234^{* * *}$ & 0.721 & 0.772 & 0.601 & 0.615 & $13.071^{* * *}$ & $-12.808^{* * *}$ \\
\hline MILDA & $-0.360^{* * *}$ & 0.175 & 0.173 & 0.101 & 0.089 & $18.979 * * *$ & $-17.294^{* * *}$ \\
\hline MIAG & $0.143^{* * *}$ & 0.697 & 0.502 & 0.866 & 0.595 & $-7.064^{* * *}$ & $-7.571^{* * *}$ \\
\hline MIRG & $-0.097^{* * *}$ & 0.104 & 0.110 & 0.060 & 0.059 & $5.452 * * *$ & $-6.718^{* * *}$ \\
\hline MIEG & -0.027 & 0.083 & 0.145 & 0.073 & 0.135 & 1.604 & -1.176 \\
\hline GB & $-0.085^{* * *}$ & 0.008 & 0.008 & 0.007 & 0.007 & $3.140 * * *$ & $-8.241 * * *$ \\
\hline EIR & $-0.179^{* * *}$ & 0.094 & 0.106 & 0.078 & 0.071 & $9.941 * * *$ & $-9.568^{* * *}$ \\
\hline GDPG & $-0.092^{* * *}$ & 0.155 & 0.126 & 0.14 & 0.124 & $4.876^{* * *}$ & $-5.875^{* * *}$ \\
\hline
\end{tabular}

${ }^{*} p<0.1,{ }^{* *} p<0.05,{ }^{* * *} p<0.01$.

Table 5 includes descriptive statistics, correlation analysis for HHI with a set of both grouping variables (organizational and non-organizational) to analyze the stipulated hypothetical relationships between them at $1 \%, 5 \%$, and $10 \%$ level of significance. The t-test and Wilcoxon test are calculated to see the differences in debt specialization between the first and fourth quartiles of HHI.

These results indicate that mature firms with more growth opportunities, maintaining high cash holding, current ratio and return on asset ratio, having a higher value of risk for earnings volatility, default risk, and return on asset volatility are significantly involved in debt specialization. These firms have high ratios for depreciation and operating expenses. They are also dividend-paying that belong to the regulatory industry, having a high median industry market to book ratio, high dividend payout, and yield ratios. In contrast, the larger, profitable companies, with more tangible assets, and high earnings growth and leverage, including financial leverage, long-term debt to asset, and market leverage, use diversified debt types. These companies are also group affiliated, have a credit rating, 
and have high financial and median industry leverage ratios. These results specify that debt specialization is a widespread phenomenon that is equally important among all publicly traded companies irrespective of their profitability, age, credit rating, and dividend payments. We show that the main reasons for adopting a debt specialization strategy in small, new, and less profitable companies are to minimize bankruptcy cost, agency conflicts, information asymmetry, limited access to some segments of the debt markets. Large, profitable, and mature companies adopt this strategy due to a good market reputation, high operational risk, and reduced flotation cost.

Table 5. Applicability of debt specializations strategy across organizations.

\begin{tabular}{|c|c|c|c|c|c|c|}
\hline Variables & Category & $\mathbf{N}$ & Mean & SD & $t$-Test & Wilcoxon Test \\
\hline \multirow{2}{*}{ Credit Rating } & Unrated & 940 & 0.233 & 0.356 & \multirow{2}{*}{0.243} & \multirow{2}{*}{0.219} \\
\hline & Rated & 876 & 0.292 & 0.381 & & \\
\hline \multirow{2}{*}{$\begin{array}{l}\text { Business Group } \\
\text { Affiliation }\end{array}$} & Affiliated & 727 & 0.367 & 0.315 & \multirow{2}{*}{$5.751^{* * *}$} & \multirow{2}{*}{$-5.354^{* * *}$} \\
\hline & Unaffiliated & 1089 & 0.406 & 0.306 & & \\
\hline \multirow{2}{*}{$\begin{array}{l}\text { Dividend } \\
\text { Payments }\end{array}$} & Not Paying & 817 & 0.415 & 0.282 & \multirow{2}{*}{-2.861} & \multirow{2}{*}{$-3.105^{* * *}$} \\
\hline & Paying & 999 & 0.483 & 0.270 & & \\
\hline \multirow{2}{*}{ Regulation } & Non-Regulated & 1435 & 0.318 & 0.339 & \multirow{2}{*}{$-4.091^{* * *}$} & \multirow{2}{*}{$-4.206^{* * *}$} \\
\hline & Regulated & 381 & 0.397 & 0.391 & & \\
\hline \multirow{2}{*}{ Size } & Small & 569 & 2.436 & 0.373 & \multirow[b]{2}{*}{$6.359 * * *$} & \multirow{2}{*}{$-5.569 * *$} \\
\hline & Large & 685 & 4.284 & 0.284 & & \\
\hline \multirow{2}{*}{ Age } & New & 692 & 12.201 & 0.239 & \multirow{2}{*}{$-2.350^{* *}$} & \multirow{2}{*}{-1.568} \\
\hline & Old & 436 & 30.506 & 0.274 & & \\
\hline
\end{tabular}

\subsection{Applicability of Debt Specialization Strategy across Organizations}

This study performs a group-wise analysis to confirm the relevance of debt specialization strategy across various types of organizations. A comparative analysis of traditional organizational and non-organizational characteristics: age, size, regulations, business group affiliation, dividend payments, and credit rating is conducted by following the way of Khan [6]. First, we segregate the sample firms involved in debt specialization ("1816 firm-year" observations) and then define the grouping variables. Here, new and small companies are those that fall in the 1st Quartile while old and large companies are related to the 4 th Quartile. The regulations, business group affiliation, credit rating, and dividend payments are the dummy variables with value " 1 " for a regulatory, group affiliated, rated, and dividend-paying companies or " 0 " otherwise.

The comparison results reveal no significant differences between the age, dividend payment, and credit rating groups of the firms that follow debt specialization strategy. All types of organizations: new or old, rated or unrated, and either pay dividends or not, follow this strategy. These results specify that debt specialization is a universal phenomenon among all publicly traded companies of Pakistan irrespective of age, dividend payments, and credit rating. Table 5 further provides significant evidence of favoring size, regulations, and business group affiliation. It illustrates a significant difference in the characteristics of the regulatory or non-regulatory, small or large, and group affiliated or unaffiliated companies. This phenomenon is more pronounced in small, regulated, and group-affiliated companies.

\subsection{Empirical Evidence for Core Factor Identification}

For the selection of core predictors, we use two different methods. Firstly, we apply stepwise regression analysis on all the categorical groups of the variables to take a general view of the essential predictors of debt specialization (See Table 6). Columns 1 and 2 reported the results for the complete sample variables (Overall: thirteen-nine). These findings are based on the combined results of backward and forward stepwise regression 
methods. The models report almost similar results except for dividend payout ratio, governmental borrowings, and interest coverage ratio, calculated from backward and forward models, respectively. Therefore, we exclude both the conflicting ratios and end up with seventeen crucial factors common in both types of analyses. These factors represented all the categories of the predictors included in the study except growth and the stock market.

Table 6. Estimation of important predictors using stepwise regression analysis.

\begin{tabular}{ccc}
\hline & Coefficient & $\boldsymbol{t}$-Statistics \\
\cline { 2 - 3 } Factors & $\mathbf{( 1 )}$ & $\mathbf{( 2 )}$ \\
\hline CH & 0.187 & 3.714 \\
CR & 0.031 & 8.746 \\
FL & -0.092 & -4.340 \\
AT & -0.121 & -4.930 \\
TATR & -119 & -5.781 \\
EV & 0.009 & 9.120 \\
DR & 0.136 & 3.125 \\
Size & -0.0082 & -7.999 \\
OER & -0.072 & -11.924 \\
GPM & 0.165 & 6.041 \\
FR & 0.092 & 3.581 \\
Reg & -0.162 & -5.821 \\
MILDA & 0.062 & 5.761 \\
EIR & -0.724 & -10.935 \\
Rating & -0.901 & -5.992 \\
Age & 0.021 & 3.652 \\
Constant & 0.219 & 4.492 \\
No. of obs. & 0.918 & 27.621 \\
R & 2795 & \\
Adj. R & 0.495 & \\
\hline Note: All the variables are significant at a $1 \%$ level of significance.
\end{tabular}

Secondly, we follow Chang [59] and Frank [2] for core factor selection after a slight modification. These researchers used the BIC approach, one of the commonly employed model selection criteria in capital structure research, to estimate the relevant predictors from a long list of explanatory factors. During the model-fitting process, the likelihood ratio can be increased simply by including more parameters, but the same can cause over-fitting of the model. BIC approach helps resolve such issues by deciding which of the essential factors to retain in the model and exclude. Therefore, we apply BIC approach to all the variables jointly and find out reliably distinguished core predictors of debt specialization from the list of thirty-nine factors by introducing penalty term for the number of parameters in the model, specified as follow:

$$
\text { BIC }=-2 \times \log \text {-likelihood }+\mathrm{P} \times \log (\mathrm{N})
$$

where P stands for "number of observations" and $\mathrm{N}$ for "number of observations". Here, the smaller value of BIC is considered "optimal". The value of BIC increases as the number of parameters or observations increases in the model, or it decreases when loglikelihood increases.

The model selection criteria of core predictor identification are based on the Chang [59] and Frank [2] process: (1) regress HHI on all variables of the category and record their coefficient and $t$ statistics; (2) eliminate the variable having minimum $t$ statistics among the group variables and regress $\mathrm{HHI}$ on the remaining; (3) repeat the process on each of the variables until only one left; (4) record cumulative $\mathrm{R}^{2}$ and BIC value on each step and select the model with lowest BIC as an optimal model; (5) report own $\mathrm{R}^{2}$ which is the $\mathrm{R}^{2}$ of the worst-performing variable, calculated through a simple univariate regression analysis; 
and (6) this process is continued and first applied to the whole sample. Then, randomly divided the overall sample data into ten equal groups and repeated the selection process on each of the subsamples; (7) finally, applied the selection process on annual subsamples independently. We also identified the optimal model based on minimum BIC specification in steps (6) and (7) from each sample group.

The rule of thumb for the core factor identification is: (1) must include in the lowest BIC specification on the whole sample; (2) include in at least $50 \%$ of the minimum BIC specification on random subsamples, and the coefficient estimate has a consistent sign across these specifications; and (3) included in at least $50 \%$ of the minimum BIC specifications on annual subsamples, and the coefficient estimate has a consistent sign across these specifications. In Table 7, the identified core factors which are discussed above are size $\left(R^{2}=12.9 \%\right)$, gross profit margin $\left(R^{2}=9.2 \%\right)$, industry long-term debt to asset ratio $\left(R^{2}=7.2 \%\right)$, long-term debt to asset ratio $\left(R^{2}=5.7 \%\right)$, asset tangibility $\left(R^{2}=5.2 \%\right)$, and age $\left(R^{2}=4.5 \%\right)$. The aggregate $R^{2}$ value of the identified core factors is approximately $45 \%$.

Table 7. Core factor selection using $\mathrm{HHI}$ as the dependent variable.

\begin{tabular}{|c|c|c|c|c|c|c|c|c|c|}
\hline Factors & Coefficient & $t$-Statistics & Own $R^{2}$ & Cumulative $\mathbf{R}^{2}$ & BIC & $\begin{array}{c}\text { Group } \\
\text { Positive (\%) }\end{array}$ & $\begin{array}{c}\text { Group } \\
\text { Negative (\%) }\end{array}$ & $\begin{array}{c}\text { Year } \\
\text { Positive (\%) }\end{array}$ & $\begin{array}{c}\text { Year } \\
\text { Negative (\%) }\end{array}$ \\
\hline & (1) & (2) & (3) & (4) & (5) & (6) & (7) & (8) & (9) \\
\hline Size & -0.0591 & -8.465 & 0.129 & 0.129 & -998.565 & 0 & 100 & 0 & 100 \\
\hline GMR & -0.381 & -7.211 & 0.092 & 0.221 & -984.854 & 0 & 90 & 0 & 100 \\
\hline MILDA & -0.892 & -6.152 & 0.072 & 0.293 & -929.546 & 0 & 90 & 0 & 100 \\
\hline LDA & -0.223 & -8.564 & 0.057 & 0.350 & -843.073 & 0 & 90 & 0 & 71 \\
\hline FR & -0.206 & -6.754 & 0.007 & 0.357 & -824.207 & 0 & 40 & 0 & 86 \\
\hline AT & -0.161 & -5.328 & 0.052 & 0.409 & -893.589 & 0 & 60 & 0 & 100 \\
\hline ML & -0.172 & -6.545 & 0.008 & 0.417 & -765.613 & 0 & 80 & 0 & 14 \\
\hline FL & -0.205 & -8.651 & 0.009 & 0.426 & -731.439 & 0 & 40 & 0 & 71 \\
\hline DPR & 0.059 & 3.421 & 0.001 & 0.427 & -714.848 & 70 & 0 & 57 & 0 \\
\hline Age & 0.001 & 4.781 & 0.045 & 0.472 & -912.039 & 100 & 0 & 71 & 0 \\
\hline TR & -0.005 & -0.495 & 0.002 & 0.474 & -814.450 & 0 & 50 & 0 & 29 \\
\hline NPR & -0.004 & -0.924 & 0.001 & 0.475 & -821.884 & 0 & 80 & 0 & 43 \\
\hline Reg. & 0.066 & 5.734 & 0.003 & 0.478 & -821.021 & 90 & 0 & 100 & 0 \\
\hline RG & -0.054 & -3.961 & 0.002 & 0.480 & -813.561 & 0 & 100 & 0 & 86 \\
\hline EBITDA & -0.024 & -0.751 & 0.003 & 0.483 & -811.565 & 0 & 40 & 0 & 57 \\
\hline DR & -0.017 & -3.821 & 0.001 & 0.483 & -810.565 & 0 & 10 & 0 & 43 \\
\hline EG & -0.001 & -0.341 & 0.001 & 0.484 & -808.552 & 0 & 40 & 0 & 71 \\
\hline GB & -4.729 & -3.431 & 0.007 & 0.491 & -804.494 & 0 & 70 & NA & NA \\
\hline EIR & -1.206 & -5.351 & 0.002 & 0.493 & -802.101 & 0 & 90 & 0 & 14 \\
\hline DY & -0.072 & -0.981 & 0.000 & 0.493 & -800.417 & 0 & 90 & 0 & 43 \\
\hline MIAG & 0.036 & 6.542 & 0.009 & 0.502 & -789.192 & 90 & 0 & 43 & 0 \\
\hline Rating & -0.008 & -1.740 & 0.000 & 0.502 & -764.315 & 0 & 90 & 0 & 14 \\
\hline$A G$ & -0.042 & -2.040 & 0.002 & 0.504 & -755.196 & 0 & 100 & 0 & 43 \\
\hline ROAV & -0.135 & -2.040 & 0.000 & 0.504 & -689.931 & 0 & 90 & 0 & 43 \\
\hline DP & -2.920 & -0.127 & 0.000 & 0.504 & -688.454 & 0 & 100 & 0 & 47 \\
\hline MBR & -0.016 & -3.561 & 0.001 & 0.505 & -687.246 & 0 & 90 & 0 & 57 \\
\hline Dep. & -0.121 & -3.015 & 0.001 & 0.506 & -679.251 & 0 & 45 & 0 & 71 \\
\hline MIEG & -0.016 & -2.125 & 0.000 & 0.506 & -679.112 & 0 & 45 & 0 & 21 \\
\hline MIFL & -0.328 & -1.998 & 0.002 & 0.508 & -676.558 & 0 & 100 & 0 & 29 \\
\hline ICR & -1.210 & -3.279 & 0.001 & 0.509 & -674.725 & 0 & 100 & NA & NA \\
\hline BGA & -0.034 & -2.485 & 0.001 & 0.511 & -658.603 & 0 & 90 & 0 & 71 \\
\hline MIRG & -0.091 & -2.974 & 0.001 & 0.512 & -654.905 & 0 & 80 & 0 & 29 \\
\hline GDPG & -0.312 & -3.054 & 0.001 & 0.513 & -635.376 & 0 & 90 & 0 & 57 \\
\hline MIML & -0.236 & -2.746 & 0.000 & 0.513 & -633.428 & 0 & 100 & 0 & 43 \\
\hline $\mathrm{CH}$ & 0.472 & 7.854 & 0.002 & 0.515 & -624.265 & 27 & 0 & 0 & 0 \\
\hline EV & 0.421 & 7.542 & 0.003 & 0.518 & -621.875 & 21 & 0 & 0 & 0 \\
\hline OER & 0.230 & 8.125 & 0.003 & 0.520 & -610.455 & 10 & 0 & 0 & 0 \\
\hline TATR & 0.009 & 6.451 & 0.001 & 0.521 & -604.746 & 7 & 0 & 0 & 0 \\
\hline CR & 0.049 & 1.754 & 0.001 & 0.522 & -604.554 & 2 & 0 & 0 & 0 \\
\hline
\end{tabular}

These results showed that only one probability factor, i.e., the gross profit margin, is included in the core predators' list, which is positively related to the debt specialization decision of the organization. These findings are supported by Rajan [10] and Titman [45], who confirmed profitable companies with high cash flows prefer to use more debt due to tax benefits and less likelihood of bankruptcy. The pecking order theory supports this notion by adding that profitable companies use less debt. The negative relations of longterm debt to asset ratio, size, and asset tangibility are pertinent to the trade-off, pecking order, signaling, and agency cost theory. These factors play a striking role in reducing information asymmetry [24], the likelihood of insolvency, agency conflicts, and increased 
accessibility to the external markets [78]. They also provide positive signals about the company's performance in the market [27]. That is why Wang [79] and Xavier [55] argued financial institutions consider them more reliable for granting loans due to their cross securities and good reputation [52,53].

On the contrary, age is positively related to debt specialization. This supports the empirical findings of Albring [70] and Lopez-Gracia [46], who stated that companies with a high risk of volatile earnings, growth opportunities, and expense ratios experience more agency-related issues and face high costs of financial distress. These factors also cause information asymmetry as investors and lenders cannot predict future earnings based on the publicly available information $[45,65]$.

Accordingly, these companies tend to prefer debt specialization strategy to avoid the likelihood of financial distress, agency cost, information collection, and monitoring cost. However, the results for age are antithetical to the previous studies by Chang [59], who believed older companies use more types of debt and against the findings of Povoa [12], who stated age does not impact the financing choices of the organizations. This study provides a piece of new evidence for this kind of relationship by adding that mature companies lean more towards debt specialization strategy because they are in a better bargaining position due to their reputation. Consequently, they often follow a cost-minimizing strategy and select few types of debt in their debt structure. The core predictor identified in this study related to the industry category is the long-term industry debt to asset ratio. These empirical outcomes for industry factors support the notion of Denis [71] and Rajan [10] that financial managers use median industry long-term debt to asset ratio as a benchmark for their companies. Trade-off theory provides theoretical support to this claim by suggesting companies with high median industry leverage use less debt [2].

We have identified some other factors which are fulfilling the criteria of minimum BIC, e.g., default risk, dividend payout ratio, GDP growth ratio, regulation, and business group affiliation, but these factors are rejected due to that the coefficient of estimation was not consistent throughout the specification. Their cumulative $\mathrm{R}^{2}$ value was shallow. These results depict that debt specialization strategy is shared among all Pakistani companies. Companies adopt it to minimize bankruptcy costs, reduce agency conflicts, information asymmetry, limited access to the debt markets, build a good market reputation, deal with high operational risk, reduce and reduce flotation costs [88].

\section{Conclusions}

This study provides new empirical evidence on the patterns of debt financing and antecedents of debt specialization. The results show that about $65 \%$ of the organizations exclusively rely on one type of debt. Only large, profitable companies with many tangible assets, high earnings growth, and leverage use diversified types of debt. These companies are group affiliated, having a credit rating and larger debt maturities with high financial ratios and median industry leverage ratios. The outcomes of the present study also provide mounting proof for the most critical predictors of debt specialization: gross profit margin, long-term debt to asset ratio, firm size, age, asset tangibility, and industry long-term debt to asset ratio. It further validates that empirically testified predictors of debt specialization are equally important in the context of developing countries like Pakistan, even in the presence of distinct institutional, economic, and cultural differences.

This study presents a new insight into the existence and relevance of debt specialization strategy across organizations. We explain that debt specialization is a widespread phenomenon that is equally important among all types of publicly traded companies irrespective of their age, dividend payments, and credit rating. We show that the main reasons for adopting a debt specialization strategy in small, new, and -paying companies are to minimize bankruptcy cost, agency conflicts, information asymmetry, and limited access to some debt markets segments. Large, profitable, and mature companies adopt this strategy due to a good market reputation, high operational risk, and reduced flotation cost. 


\subsection{Implication of the Study}

This study will assist scholars and practitioners in understanding why companies follow debt specialization strategy. First, it highlights the importance of sophisticated mathematical modeling in corporate finance studies. It explains how mathematical techniques help find out the solution to complicated financial problems like debt structure composition. Second, it enhances our understanding of the capital structure studies and optimal contracting literature by specifying that the composition of debt and heterogeneity in debt structure has an important implication in designing the optimal debt contracts. It also explains the causes; why organizations include a specific type of debt in their debt structure. Third, it will guide the financial managers to properly design their strategies by having appropriate types of debt, which can adequately manage the economic crunch and increase the firm value. The management is more interested in the inputs from the functional areas of finance, such as capital structure, to design their financial strategy. For that purpose, they seek guidance from available mathematical tools for correctly evaluating the risk attached to each type of debt. This joint review will help explain the financing choices of the organizations, especially with reference to debt structure. Additionally, it will guide the financial managers to focus on debt types that have fewer contractual restrictions, minimize the financing and operating cost, and match the tenor of the assets.

Finally, the study verdicts reveal that the policymakers should work on the potential areas like restructuring of internal bond markets of Pakistan. There are very few people who prefer corporate bonds; that is why around five percent of the organizations use bonds for their financing. There is a need to develop a fully designed and operational domestic debt market that provides a cheap solution for financing to the public limited companies of Pakistan.

\subsection{Limitations and Scope of the Study}

Current research has successfully created a wide web of debt specialization that will provide new dimensions to future researchers. First, it identifies a long list of organizational factors; future researchers will empirically test these factors and suggest which factors are reliably signed and reliably important for predicting debt specialization.

Though the statistics are sufficient and give us all necessary information about the background of debt specialization, the panel data we get were for a shorter period, and data were unavailable before the specified period. So, it has limited our analysis on cross-sectional heterogeneity in debt specialization Colla [13].

Second, we have used credit rating as one of the debt market factors to assess a company's ability to meet its financial obligations. Still, only $17 \%$ of the Pakistani companies have a credit rating. So, it is suggested to future researchers to use the distance to default [89] or market beta as a measure of financial credibility in place of credit rating. Similarly, there is a need to introduce new measures for debt specialization and add cashflow metrics in future research on the topic. Thirdly, the current study indicates the existence of debt specialization and offer six unique kinds of debts which are as follows: (1) short term secured debts, (2) short term other debts, (3) long term secured debts, (4) long term other debts, (5) long term unsecured debts, (6) bonds, and other long term debts. If we compare these types of debts with prior studies, they are more generic, Lou [77] and Rouh [14]. The State bank of Pakistan has started to categorize these types of debts since 2009. Before 2009, debts used to be divided into two categories, short-term debts, and long-term debts. For future studies, we can use a particular type of debt to assess the influence of identified factors. It can also provide new insights into the debt specialization strategy.

Fourth, this study ignores the effect of the financial crisis on the debt structure composition, while researchers reported that financial crisis evolves the choices of firm debt structure [90-92]. Therefore, it is suggested that future researchers may find out the pre and post effect of the financial crisis on debt specialization decisions of the companies. Fifth, it has utilized three different stock market factors as an evaluation tool to measure investors' perceptions about the organizations' prospects based on current performance. 
However, all proxies used are related to the cash dividends paid while stock dividends include only the dummy variable "Dividend Payers." Future researchers may consist of other forms of dividend payouts, stock dividends, and share buybacks.

Author Contributions: Conceptualization, K.I.K. and F.Q.; Data curation, K.I.K. and M.N.M.; Formal analysis, K.I.K.; Investigation, F.Q. and J.A.F.; Methodology, K.I.K. and Q.u.A.S.; Resources, J.C.N. and J.A.F.; Software, K.I.K., Q.u.A.S. and J.A.F.; Supervision, F.Q.; Writing-original draft, K.I.K. and F.Q.; Writing-review \& editing, K.I.K., F.Q. and J.N.M. All authors have read and agreed to the published version of the manuscript.

Funding: This research received no external funding.

Data Availability Statement: Data can be provided on request.

Acknowledgments: We are thankful to the anonymous reviewers for their suggestions regarding categorizing and measuring the variables.

Conflicts of Interest: The authors declare no conflict of interest.

\section{Appendix A}

Table A1. Table of Acronym.

\begin{tabular}{|c|c|c|c|c|c|c|c|}
\hline Variables & Acronym & Variables & Acronym & Variables & Acronym & Variables & Acronym \\
\hline Cash Holding & $\mathrm{CH}$ & Asset Growth & AG & Dividend Payers & DP & Liquidity & LIQ \\
\hline Current Ratio & CR & Sale Growth & SG & $\begin{array}{c}\text { Dividend Payout } \\
\text { Ratio }\end{array}$ & DPR & Profitability & PROF \\
\hline $\begin{array}{l}\text { Gross Margin } \\
\text { Ratio }\end{array}$ & GMR & Earnings Growth & EG & Dividend Yield & DY & Leverage & LEV \\
\hline $\begin{array}{l}\text { EBITDA Margin } \\
\text { Ratio }\end{array}$ & EBITDA & $\begin{array}{l}\text { Business Group } \\
\text { Affiliation }\end{array}$ & BGA & Regulation & Reg. & Nature of Asset & NOA \\
\hline Net Profit Ratio & NPR & Size & Size & $\begin{array}{l}\text { Median Industry } \\
\text { Financial } \\
\text { Leverage }\end{array}$ & MIFL & Risk & RISK \\
\hline $\begin{array}{l}\text { Financial } \\
\text { Leverage }\end{array}$ & FL & Age & Age & $\begin{array}{l}\text { Median Industry } \\
\text { Long-term Debt } \\
\text { to Assets }\end{array}$ & MILDA & Growth & GROW \\
\hline Market Leverage & ML & $\begin{array}{l}\text { Market to Book } \\
\text { Growth }\end{array}$ & MBR & $\begin{array}{l}\text { Median Industry } \\
\text { Market Leverage }\end{array}$ & MIML & $\begin{array}{l}\text { Controlling } \\
\text { Authority }\end{array}$ & CA \\
\hline $\begin{array}{l}\text { Long-term Debt } \\
\text { to Assets }\end{array}$ & LDA & $\begin{array}{l}\text { Depreciation } \\
\text { Ratio }\end{array}$ & Dep. & $\begin{array}{l}\text { Median Industry } \\
\text { Asset Growth }\end{array}$ & MIAG & Market & MARK \\
\hline Asset Tangibility & $\mathrm{AT}$ & $\begin{array}{c}\text { Operating } \\
\text { Expense Ratio }\end{array}$ & OER & $\begin{array}{l}\text { Median Industry } \\
\text { Sale Growth }\end{array}$ & MISG & $\begin{array}{l}\text { Nature of } \\
\text { Expenses }\end{array}$ & $\mathrm{NOE}$ \\
\hline $\begin{array}{c}\text { Total Asset } \\
\text { Turnover Ratio }\end{array}$ & TATR & Tax Ratio & TR & $\begin{array}{l}\text { Median Industry } \\
\text { Earnings Growth }\end{array}$ & MIEG & Debt Market & $\mathrm{DM}$ \\
\hline $\begin{array}{l}\text { Earnings } \\
\text { Volatility }\end{array}$ & EV & Credit Rating & Rating & $\begin{array}{l}\text { Government } \\
\text { Borrowing }\end{array}$ & GB & Stock Market & SM \\
\hline Default Risk & DR & Financial Ratio & FR & $\begin{array}{c}\text { Expected } \\
\text { Inflation Rates }\end{array}$ & EIR & Industry & IND \\
\hline $\begin{array}{l}\text { Return on Asset } \\
\text { Volatility }\end{array}$ & ROAV & $\begin{array}{c}\text { Interest } \\
\text { Coverage Ratio }\end{array}$ & ICR & GDP Growth & GDP Gro. & Macroeconomic & MACRO \\
\hline $\begin{array}{l}\text { Short Term } \\
\text { Secured Debts }\end{array}$ & SSD & $\begin{array}{l}\text { Short Term } \\
\text { Other Debts }\end{array}$ & OSD & $\begin{array}{l}\text { Long Term } \\
\text { Secured Debts }\end{array}$ & LSD & $\begin{array}{c}\text { Long Term } \\
\text { Unsecured Debts }\end{array}$ & LUND \\
\hline Debenture & DEB & $\begin{array}{l}\text { Other } \\
\text { Long-Term } \\
\text { Debts }\end{array}$ & OLD & Total Debts & $\mathrm{TD}$ & & \\
\hline
\end{tabular}

\section{References}

1. Nosratabadi, S.; Mosavi, A.; Shamshirband, S.; Zavadskas, E.K.; Rakotonirainy, A.; Chau, K.W. Sustainable business models: A review. Sustainability 2019, 11, 1663. [CrossRef]

2. Frank, M.Z.; Goyal, V.K. Capital structure decisions: Which factors are reliably important? Financ. Manag. 2009, 38, 1-37. [CrossRef]

3. Graham, J.R.; Leary, M.T. A review of empirical capital structure research and directions for the future. Annu. Rev. Financ. Econ. 2011, 3, 309-345. [CrossRef] 
4. Graham, J.R.; Leary, M.T.; Roberts, M.R. A century of capital structure: The leveraging of corporate America. J. Financ. Econ. 2015, 118, 658-683. [CrossRef]

5. Azofra, V.; Castrillo, L.; del Mar Delgado, M. Ownership concentration, debt financing and the investment opportunity set as determinants of accounting discretion: Empirical evidence from Spain. Spanish J. Financ. Account. Rev. Española Financ. Contab. 2003, 32, 215-255. [CrossRef]

6. Khan, K.I.; Qadeer, F.; John, A.; Sheeraz, M. Existence and prevalence of debt specialization strategy across organizations: A Pakistani perspective. Pakistan J. Commer. Soc. Sci. 2016, 10, 461-485. Available online: http://jespk.net/publications/320.pdf (accessed on 5 December 2020).

7. Khan, K.I.; Qadeer, F.; Rizavi, S.S.S.; Mahmood, S.; Rizavi, S.S.S. Reasons of debt specialization: Understanding the perspectives of small and large organizations. Lahore J. Bus. 2017, 6, 93-110. [CrossRef]

8. Malik, Q.U.Z.; Afza, T. Do group affiliated firms specialize in debt? Evidence from Pakistan. J. Econ. Adm. Sci. 2016, 32, 46-62. [CrossRef]

9. Goodell, J.W.; Goyal, A. What determines debt structure in emerging markets: Transaction costs or public monitoring? Int. Rev. Financ. Anal. 2018, 55, 184-195. [CrossRef]

10. Rajan, R.G.; Zingales, L. What do we know about capital structure? Some evidence from international data. J. Financ. 1995, 50, 1421-1460. [CrossRef]

11. Booth, L.; Aivazian, V.; Demirguc-Kunt, A.; Maksimovic, V. Capital structures in developing countries. J. Financ. 2001, 56, 87-130. [CrossRef]

12. Povoa, A.C.S.; Nakamura, W.T. Homogeneity versus heterogeneity in debt structure: A study using panel data. Account. Financ. Rev. 2014, 25, 19-32. [CrossRef]

13. Colla, P.; Ippolito, F.; Li, K.A.I. Debt specialization. J. Financ. 2013, 68, 2117-2141. [CrossRef]

14. Rauh, J.D.; Sufi, A. Capital structure and debt structure. Rev. Financ. Stud. 2010, 23, 4242-4280. [CrossRef]

15. Lemmon, M.L.; Roberts, M.R.; Zender, J.F. Back to the beginning: Persistence and the cross-section of corporate capital structure. J. Financ. 2008, 63, 1575-1608. [CrossRef]

16. Giannetti, C. Debt specialization and performance of European firms. J. Empir. Financ. 2019, 53, 257-271. [CrossRef]

17. Kraus, A.; Litzenberger, R.H. A state-preference model of optimal financial leverage. J. Financ. 1973, 28, 911-922. [CrossRef]

18. Baker, H.K.; Martin, G.S. Capital Structure and Corporate Financing Decisions: Theory, Evidence, and Practice, 1st ed.; John Wiley \& Sons: Hoboken, NJ, USA, 2011; ISBN 0470569522.

19. Harris, M.; Raviv, A. The theory of capital structure. J. Financ. 1991, 46, 297-355. [CrossRef]

20. Baker, H.K.; Powell, G.E.; Veit, E.T. Revisiting managerial perspectives on dividend policy. J. Econ. Financ. 2002, 26, 267-283. [CrossRef]

21. Khan, K.I.; Qadeer, F.; Ghafoor, M.M. Debt specialization within profitability sub-groups: A new perspective of debt structure choices. FWU J. Soc. Sci. 2017, 11, 92-108.

22. Myers, S.C. The capital structure puzzle. J. Financ. 1984, 39, 574-592. [CrossRef]

23. Arena, M.P. The corporate choice between public debt, bank loans, traditional private debt placements, and 144 A debt issues. Rev. Quant. Financ. Account. 2011, 36, 391-416. [CrossRef]

24. Kale, J.R.; Meneghetti, C. The choice between public and private debt: A survey. IIMB Manag. Rev. 2011, 23, 5-14. [CrossRef]

25. Elsas, R.; Flannery, M.J.; Garfinkel, J.A. Financing major investments: Information about capital structure decisions. Rev. Financ. 2014, 18, 1341-1386. [CrossRef]

26. Fama, E.F.; French, K.R. Testing trade-off and pecking order predictions about dividends and debt. Rev. Financ. Stud. 2002, 15, 1-33. [CrossRef]

27. Ross, S.A. The determination of financial structure: The incentive-signalling approach. Bell J. Econ. 1977, 8, 23-40. [CrossRef]

28. Jensen, M.C.; Meckling, W.H. Theory of the firm: Managerial behavior, agency costs and ownership structure. J. Financ. Econ. 1976, 3, 305-360. [CrossRef]

29. Alderson, M.J.; Bansal, N.; Betker, B.L. Secured debt and managerial incentives. Rev. Quant. Financ. Account. 2014, 43, 423-440. [CrossRef]

30. Barclay, M.J.; Smith, C.W. The priority structure of corporate liabilities. J. Financ. 1995, 50, 899-917. [CrossRef]

31. Ardalan, K. Capital structure theory: Reconsidered. Res. Int. Bus. Financ. 2017, 39, 696-710. [CrossRef]

32. Priester, C.; Wang, J. Financial Strategies for the Manager, 2nd ed.; Tsinghua University Press: Beijing, China, $2010 ;$ ISBN 3540709665.

33. Florackis, C.; Kanas, A.; Kostakis, A. Dividend policy, managerial ownership and debt financing: A non-parametric perspective. Eur. J. Oper. Res. 2015, 241, 783-795. [CrossRef]

34. Tengulov, A. The impact of borrowing diversity on firm's value, financial and real decisions. In Proceedings of the Annual Conference of the Swiss Society for Financial Market Research, Zurich, Switzerland, 10 April 2015.

35. Khan, K.I.; Nasir, A.; Arslan, A. Impact of Loan Accessibility on Working Capital Management and Profitability: Comparative Study of Family Versus Non-Family Firms. Glob. Soc. Sci. Rev. 2020, V, 220-230. [CrossRef]

36. Basu, K. Market imperfections and optimal capital structure: Evidence from Indian panel data. Glob. Bus. Rev. 2015, 16, 61-83. [CrossRef]

37. Pessarossi, P.; Weill, L. Choice of corporate debt in China: The role of state ownership. China Econ. Rev. 2013, 26, 1-16. [CrossRef] 
38. Locorotondo, R.; Dewaelheyns, N.; Van Hulle, C. Cash holdings and business group membership. J. Bus. Res. 2014, 67, 316-323. [CrossRef]

39. Danis, A.; Rettl, D.A.; Whited, T.M. Refinancing, profitability, and capital structure. J. Financ. Econ. 2014, 114, 424-443. [CrossRef]

40. Afrasiabishani, J.; Ahmadinia, H.; Hesami, E. A Comprehensive Review on Capital Structure Theories. Sch. Dr. Stud. Eur. Union J. 2012, 4, 35-45.

41. Myers, S.C.; Majluf, N.S. Corporate financing and investment decisions when firms have information that investors do not have. J. Financ. Econ. 1984, 13, 187-221. [CrossRef]

42. Kaya, H.D. The Effect of Firm Characteristics on Choice of Debt Financing. Int. J. Manag. 2011, 28, 199-208. Available online: https:/ / search.proquest.com/scholarly-journals/effect-firm-characteristics-on-choice-debt/docview/1008666418/se2?accountid=135034 (accessed on 8 December 2020).

43. Memon, Z.A.; Chen, Y.; Tauni, M.Z.; Ali, H. The impact of cash flow volatility on firm leverage and debt maturity structure: Evidence from China. China Financ. Rev. Int. 2018, 8, 69-91. [CrossRef]

44. Johnson, S.A. An empirical analysis of the determinants of corporate debt ownership structure. J. Financ. Quant. Anal. 1997, 32, 47-69. [CrossRef]

45. Titman, S.; Wessels, R. The determinants of capital structure choice. J. Financ. 1988, 43, 1-19. [CrossRef]

46. Lopez-Gracia, J.; Mestre-Barbera, R. Tax effect on Spanish SME optimum debt maturity structure. J. Bus. Res. 2011, 64, 649-655. [CrossRef]

47. Myers, S.C. Determinants of corporate borrowing. J. Financ. Econ. 1977, 5, 147-175. [CrossRef]

48. Erel, I.; Julio, B.; Kim, W.; Weisbach, M.S. Macroeconomic conditions and capital raising. Rev. Financ. Stud. 2012, 25, 341-376. [CrossRef]

49. Ozkan, A. Determinants of capital structure and adjustment to long run target: Evidence from UK company panel data. J. Bus. Financ. Account. 2001, 28, 175-198. [CrossRef]

50. Bamiatzi, V.; Cavusgil, S.T.; Jabbour, L.; Sinkovics, R.R. Does business group affiliation help firms achieve superior performance during industrial downturns? An empirical examination. Int. Bus. Rev. 2014, 23, 195-211. [CrossRef]

51. Goyal, V.K.; Wang, W. Debt maturity and asymmetric information: Evidence from default risk changes. J. Financ. Quant. Anal. 2013, 48, 789-817. [CrossRef]

52. Gopalan, R.; Nanda, V.; Seru, A. Affiliated firms and financial support: Evidence from Indian business groups. J. Financ. Econ. 2007, 86, 759-795. [CrossRef]

53. Masulis, R.W.; Pham, P.K.; Zein, J. Family business groups around the world: Financing advantages, control motivations, and organizational choices. Rev. Financ. Stud. 2011, 24, 3556-3600. [CrossRef]

54. He, J.; Mao, X.; Rui, O.M.; Zha, X. Business groups in China. J. Corp. Financ. 2013, 22, 166-192. [CrossRef]

55. Xavier, W.G.; Bandeira-de-Mello, R.; Marcon, R. Institutional environment and business groups' resilience in Brazil. J. Bus. Res. 2014, 67, 900-907. [CrossRef]

56. Han, S.H.; Kwon, Y.; Jo, E. The Knock-On Effect in Business Group: Evidence from Korean Chaebols Credit Rating Changes. In Proceedings of the 25th Australasian Finance and Banking Conference, Sydney, Australia, 16-18 December 2012.

57. Dewaelheyns, N.; Hulle, C. Van Internal capital markets and capital structure: Bank versus internal debt. Eur. Financ. Manag. 2010, 16, 345-373. [CrossRef]

58. Li, L.; Islam, S.Z. Firm and industry specific determinants of capital structure: Evidence from the Australian market. Int. Rev. Econ. Financ. 2019, 59, 425-437. [CrossRef]

59. Chang, C.; Chen, X.; Liao, G. What are the reliably important determinants of capital structure in China? Pacific-Basin Financ. J. 2014, 30, 87-113. [CrossRef]

60. Flannery, M.J. Asymmetric information and risky debt maturity choice. J. Financ. 1986, 41, 19-37. [CrossRef]

61. Joeveer, K. Firm, country and macroeconomic determinants of capital structure: Evidence from transition economies. J. Comp. Econ. 2013, 41, 294-308. [CrossRef]

62. Chemmanur, T.J.; Fulghieri, P. Reputation, renegotiation, and the choice between bank loans and publicly traded debt. Rev. Financ. Stud. 1994, 7, 475-506. [CrossRef]

63. Lemmon, M.L.; Zender, J.F. Debt Capacity and Tests of Capital Structure Theories. J. Financ. Quant. Anal. 2010, 45, 1161-1187. [CrossRef]

64. Faulkender, M.; Petersen, M.A. Does the source of capital affect capital structure? Rev. Financ. Stud. 2006, 19, 45-79. [CrossRef]

65. Meneghetti, C. Managerial incentives and the choice between public and bank debt. J. Corp. Financ. 2012, 18, 65-91. [CrossRef]

66. Baker, M.; Wurgler, J. Market timing and capital structure. J. Financ. 2002, 57, 1-32. [CrossRef]

67. Grjebine, T.; Szczerbowicz, U.; Tripier, F. Corporate debt structure and economic recoveries. Eur. Econ. Rev. 2018, 101, 77-100. [CrossRef]

68. Chen, H.; Hu, Y.J.; Huang, S. Monetary Incentive and Stock Opinions on Social Media. J. Manag. Inf. Syst. 2019, 36, 391-417. [CrossRef]

69. Barclay, M.J.; Smith, C.W. The maturity structure of corporate debt. J. Financ. 1995, 50, 609-631. [CrossRef]

70. Albring, S.M.; Khurana, I.K.; Nejadmalayeri, A.; Pereira, R. Managerial compensation and the debt placement decision. J. Corp. Financ. 2011, 17, 1445-1456. [CrossRef] 
71. Denis, D.J.; McKeon, S.B. Debt financing and financial flexibility evidence from proactive leverage increases. Rev. Financ. Stud. 2012, 25, 1897-1929. [CrossRef]

72. Hanssens, J.; Deloof, M.; Vanacker, T. The evolution of debt policies: New evidence from business startups. J. Bank. Financ. 2016, 65, 120-133. [CrossRef]

73. Li, N.; Lou, Y.; Otto, C.A.; Wittenberg-Moerman, R. Accounting quality and debt concentration: Evidence from internal control weakness disclosures. Work. Pap. HEC Paris 2016. [CrossRef]

74. Abor, J. Debt policy and performance of SMEs: Evidence from Ghanaian and South African firms. J. Risk Financ. 2007, 8, 364-379. [CrossRef]

75. Delen, D.; Kuzey, C.; Uyar, A. Measuring firm performance using financial ratios: A decision tree approach. Expert Syst. Appl. 2013, 40, 3970-3983. [CrossRef]

76. Alhassan, A.; Li, L.; Reddy, K.; Duppati, G. The relationship between political instability and financial inclusion: Evidence from Middle East and North Africa. Int. J. Financ. Econ. 2019. [CrossRef]

77. Lou, Y.; Otto, C. Debt Dispersion, Creditor Conflicts, and Covenants in Corporate Loans; HEC: Paris, France, 2015.

78. Shah, A.; Khan, S.A. Empirical investigation of debt-maturity structure: Evidence from Pakistan. Pak. Dev. Rev. 2009, 48, 565-578. [CrossRef]

79. Wang, H.D.; Lin, C.J. Debt financing and earnings management: An internal capital market perspective. J. Bus. Financ. Account. 2013, 40, 842-868. [CrossRef]

80. Aggarwal, R.; Kyaw, N.A. Capital structure, dividend policy, and multinationality: Theory versus empirical evidence. Int. Rev. Financ. Anal. 2010, 19, 140-150. [CrossRef]

81. Chang, H.H.; Hung, C.-J.; Hsieh, H.-W. Virtual teams: Cultural adaptation, communication quality, and interpersonal trust. Total Qual. Manag. Bus. Excell. 2014, 25, 1318-1335. [CrossRef]

82. Buchuk, D.; Larrain, B.; Muñoz, F.; Urzúa I., F. The internal capital markets of business groups: Evidence from intra-group loans. J. Financ. Econ. 2014, 112, 190-212. [CrossRef]

83. Custódio, C.; Ferreira, M.A.; Laureano, L. Why are US firms using more short-term debt? J. Financ. Econ. 2013, 108, 182-212. [CrossRef]

84. George, D. SPSS for Windows Step by Step: A Simple Study Guide and Reference, 17.0 Update, 10th ed.; Pearson Education, Inc.: Boston, MA, USA, 2010; ISBN 8131762254.

85. Tabachnick, B.G.; Fidell, L.S. Using Multivariate Statistics, 6th ed.; Pearson Education, Inc.: New York, NY, USA, 2013.

86. Maddala, G.S. Limited Dependent and Qualitative Variables in Econometrics; Cambridge University Press: Cambridge, UK, 1986; ISBN 0521338255.

87. West, S.G.; Finch, J.F.; Curran, P.J. Structural Equation Models with Non- Normal Variables: Problems and Remedies; Sage Publications, Inc.: Newbery Park, CA, USA, 1995; ISBN 9780803953185.

88. Orlova, S.; Harper, J.T.; Sun, L. Determinants of capital structure complexity. J. Econ. Bus. 2020, 110, 105905. [CrossRef]

89. Merton, R.C. On the pricing of corporate debt: The risk structure of interest rates. J. Financ. 1974, 29, 449-470. [CrossRef]

90. Dell'Erba, S.; Hausmann, R.; Panizza, U. Debt levels, debt composition, and sovereign spreads in emerging and advanced economies. Oxford Rev. Econ. Policy 2013, 29, 518-547. [CrossRef]

91. Davydov, D. Debt structure and corporate performance in emerging markets. Res. Int. Bus. Financ. 2016, 38, 299-311. [CrossRef]

92. De Fiore, F.; Uhlig, H. Corporate Debt Structure and the Financial Crisis. J. Money Credit Bank. 2015, 47, 1571-1598. [CrossRef] 